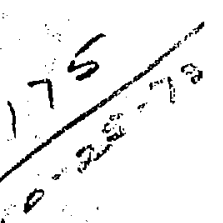

UCRL-51440

\title{
PROBLEMS WITH PREDICTING FALLOUT RADIATION HAZARD IN TACTICAL BATTLEFHELD SITUATIONS
}

\author{
A. Schiff
}

August 14, 1973

Prepared for US. Atomic Energy Commission under contract No.W-7405-Eng-48

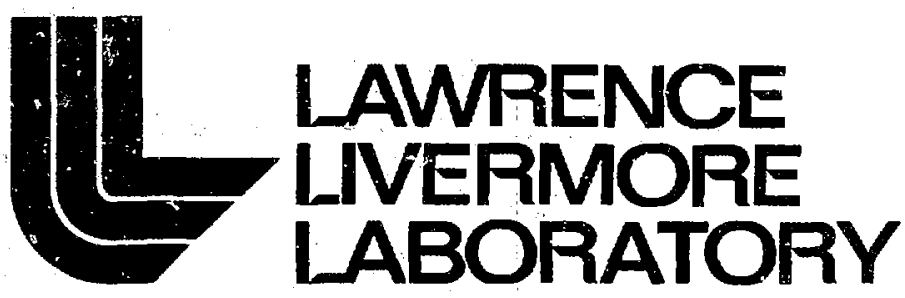

Un ersity of California/Livermore

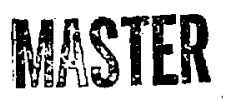

DISTRIBUTION OF THIS DOCUMENT IS UMH.IMITED 


\section{Notete}

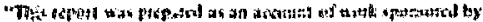

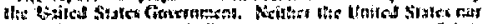

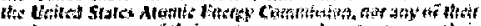

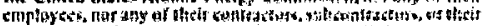

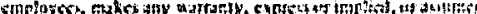

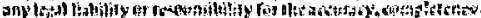

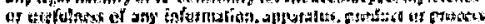

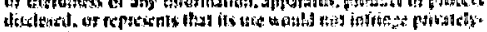

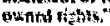

\section{Printed in the United States of America Availiable from \\ National Technical Information Service \\ U.S. Department of Commerce 5285 Port Royal Road Springfield, Virginia 22151}

Price: Printed Copy $\$$; Microfiche $\$ 0.95$

$$
\begin{gathered}
\text { Pages } \\
\hline 1-50 \\
51-150 \\
151-325 \\
326-500 \\
501-1000
\end{gathered}
$$

NTIS

Selling Price

$\$ 4.00$

$\$ 5.45$

$\$ 7.60$

$\$ 10.60$

$\$ 13.60$ 
TLD-4500, UC -32

Mathematics and Computers

\section{노 \\ LAMPENCE LUVEFMOFE LABORATORY

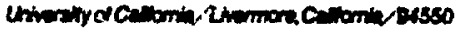

UCRL-51440

\section{PROQLEMS WITH PREDICTING FALLOUT RADIATION HAZARD IN TACTICAL BATILFIELO SITUATIONS}

A. Schiff

MS, date: Auguet 14, 1973

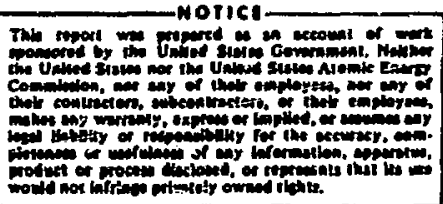

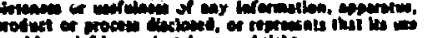

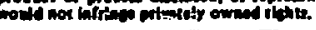




\section{Contents}

\begin{tabular}{|c|c|c|c|c|c|c|c|c|c|c|c|c|c|c|}
\hline Abstraci & & $\cdot$ & $\cdot$ & $\cdot$ & e & ${ }^{\circ}$ & . & - & & $\cdot$ & $\cdot$ & & . & \\
\hline Introduction & . & $\cdot$ & $\cdot$ & $\cdot$ & ${ }^{\circ}$ & $\cdot$ & 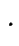 & $\cdot$ & r & . & & & . & \\
\hline Comparisons & & . & $\cdot$ & . & ${ }^{\circ}$ & 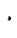 & & . & 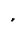 & r & ${ }^{\circ}$ & $\cdot$ & . & \\
\hline Cautionar: & $y$ Be & mark & & . & - & 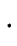 & 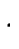 & & 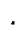 & ${ }^{\circ}$ & 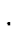 & " & . & \\
\hline Schemes for Fal & llout & Prec & dier & & • & $\cdot$ & r. & . & 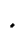 & $\cdot$ & $\cdot$ & - & 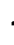 & \\
\hline DELFIC & & . & $\cdot$ & $\cdot$ & $\cdot$ & . & . & . & • & $\cdot$ & . & . & & \\
\hline PROFET & & $\cdot$ & $\cdot$ & . & - & • & $\cdot$ & $\cdot$ & ? & $\cdot$ & $\cdot$ & - & 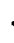 & \\
\hline SEER & . & . & . & $\cdot$ & $\cdot$ & ${ }^{\circ}$ & t & - & . & $\cdot$ & $\cdot$ & - & & \\
\hline KDFOC & $\cdot$ & . & . & - & $\cdot$ & $\cdot$ & ' & - & . & $\cdot$ & $\cdot$ & . & 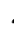 & \\
\hline WEDS & . & . & $\cdot$ & . & 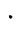 & $\cdot$ & · & . & . & $\cdot$ & $\cdot$ & . & 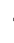 & \\
\hline U.S Arm & a $\mathrm{Fa}$ & Llout & $M$ & del & . & . & - & - & ${ }^{\circ}$ & . & $\cdot$ & $\cdot$ & . & \\
\hline NRDL D-1 & Mode & & . & $\cdot$ & . & • & . & - & $\cdot$ & • & . & • & 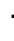 & \\
\hline Uncertain & ties & & - & · & · & . & - & - & . & $\cdot$ & $\cdot$ & • & 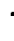 & \\
\hline Areas of Partict & ular & Unce & erts & nty & & • & - & - & 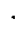 & • & - & · & r & \\
\hline Wind & · & . & . & . & · & ' & $\cdot$ & - & $\cdot$ & $\cdot$ & . & $\cdot$ & . & \\
\hline Terratn & & . & . & . & · & • & $\cdot$ & $\cdot$ & • & • & $\cdot$ & • & 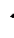 & \\
\hline Magic Nur & mber & & - & · & · & . & , & • & • & $\cdot$ & • & • & . & \\
\hline Rainost & . & · & $\cdot$ & • & · & • & • & $\cdot$ & • & $\cdot$ & • & . & . & \\
\hline Cloud Far & ramet & ters & & - & . & . & . & . & • & - & . & . & 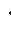 & \\
\hline Consequences &. & - & · & $\cdot$ & - & . & - & . & - & • & • & . & 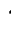 & \\
\hline Recommendation & & . & " & . & • & . & . & $\cdot$ & $\cdot$ & • & . & . & 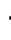 & \\
\hline Surnmary & $\cdot$ & 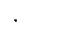 & $\cdot$ & $\cdot$ & . & $\cdot$ & . & . & . & • & ${ }^{\circ}$ & . & . & \\
\hline References & - & $\cdot$ & . & $\cdot$ & $\cdot$ & $\cdot$ & . & . & . & . & $\cdot$ & . & . & \\
\hline A,ppendix & : & . & $\cdot$ & - & . & ' & - & · & . & $\cdot$ & . & . & . & \\
\hline
\end{tabular}




\title{
PROBLEMS WITH PREDICTING FALLOUT RADIATION HAZARD IN TACTICAL BATTLEFIELD SITUATIONS
}

\begin{abstract}
Frediction capabilities are reviewed to determine whether they are suitable for deacribing the fallout radiation hazards that may exist in tactical nuclear battlefield situations. One aspect of fallout predictability is illustrated by a collection of aberrant resuits from nuclear teats conducted under fairly stabilized condtions; there are a number of warnings about the confidence that should be placed on prediction schemes derived from nuclear test shots. A comparison of current fallout models shows uncertainties including wind, terrain, rainout, and cloud parameters. Some

consequences of depending upon faulty predictions are serious. The search for the best-of-all-possible prediction Bchemeg will not lead to frultiul results becaus $:$ of the complexities involved: a set of limits to the upper and lower bounds to expected fallout should be adopted as a practical means of using prediction schemes for tactical warfare. It is emphasized that there is no gubstitute for hard data and that a computerized radiation data collection, reduction, and display system should be contemplated to satisfy the need to respond to fallout problems on the battlefield.
\end{abstract}

\section{Introduction}

Suppose the U.S. were to come to the point of engaging in a tactical nuclear battle. Several questions come to mind about such a situation. How might such a battle be conducted? How would the combat forces react? What intelligence is available to make decisions?

If one subscribes to the school of the aght that maintains that both sides will annihilate each other within $24 \mathrm{hr}$, then all other questions are moot. On the other hand, if one believes that the dominant powers would find that result unacceptable, then he could conclude that the battle would likely be fought in some methodical manner. A basic assumption of this study is that the latter would be the case, if such a taclical situation were to transpire at all.

There is a story that once, in a military commlttee considering combat forces' reactions to tactical nuclear warfare, half the officers felt that the troops would fight through it all and the other half thought there would be complete pandemonium. The conclusion, therefore, was that $50 \%$ of the troops would continue on while the other 50\% would panic. 
If field commandors could obtain the necessary fallout intelligence to determine the situation and could assure combat forces that the situation cculd be, and was being, brought under control, the fightimg strength could be improved greatly over the 50\% level. This study examines how adequately such intelligence might be acquired and used as the situation is today and what might be soms areas of improvement for the future.

\section{Comparisons}

First, let us examine the fallout intelligeree collected from previous nuclear test series. For comparison with tactical batt]efield situations, only yields up to $100 \mathrm{kt}$ have been considered.

Under test conditions, a shot go-ahead is not given unless the weather has stabilized. The predictability of results should therefore be much different than it would be in wariare. Even so, testmanagerg' reports that are readily available show some surprising results, even under the controlled conditions. A few of the more exaggerated ones are included here.

In Operation Teapot (1955), ${ }^{1}$ for instance, the Turk shot fallout \{Fig. 11, was almost

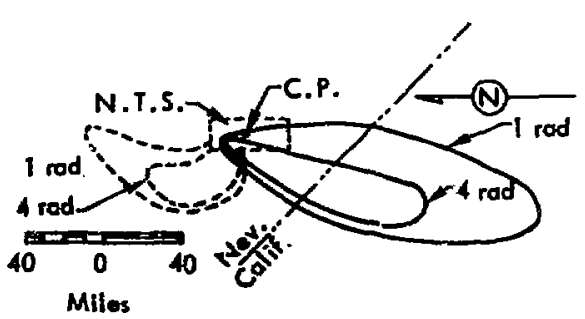

Fig. 1. Fallout from the Turk shot fired in 1955. The solid lines show the predicted fallout pattern; the dotited liner show the actual follout pattern determined by grouni survey. (Erom Ref. 1.) $180^{\circ}$ divergent from that predicted. The Apple shot (Fig. 2) was complicated by some iesidual radiation from the previous

Wasp-Prime ghot (detonated on the same day).

A later shot series called Operation Plumbbob (1957) $)^{2}$ produced a number of fallout forecasts that were mapped far from the measured radiation patterns (Figs. 3, 4, and 5). A more recent event that had data available for comparison was Schooner $(1968)^{4,5}$ (Fig. 6).

A comparison of an idealized-model prediction with a shot ${ }^{3}$ having a yield of $1 \mathrm{kt}$ is given in Fig. 7 .

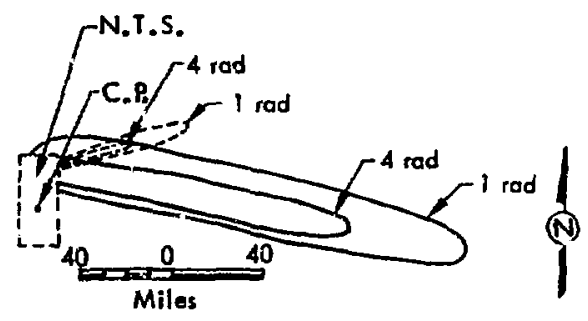

Fig. 2. Fallout from the Apple and WaspPrime shots fired in 1955. The solid lines show the predicted fallout pattern; the dotted lines show the actual callout pattern determ ined by combined air and ground surveys, (From Ref. 1.) 


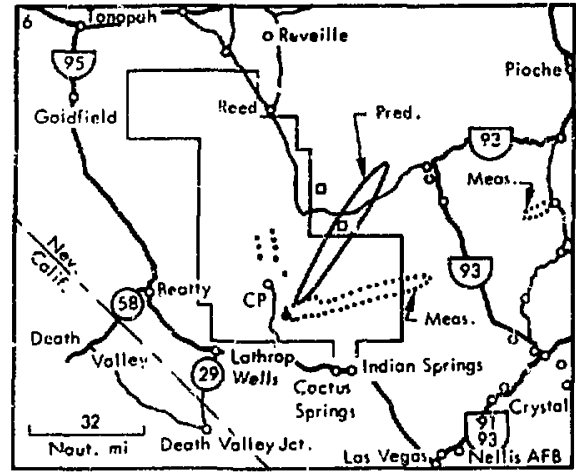

Fig. 3. Fallout from the Priscilla shot fired on June 24, 1957, from a balloon at $700 \mathrm{ft}$. The solld line shows the predicted fallout pattern; the dotted line shows the actual fallout pattern. (From Ref. 2.)

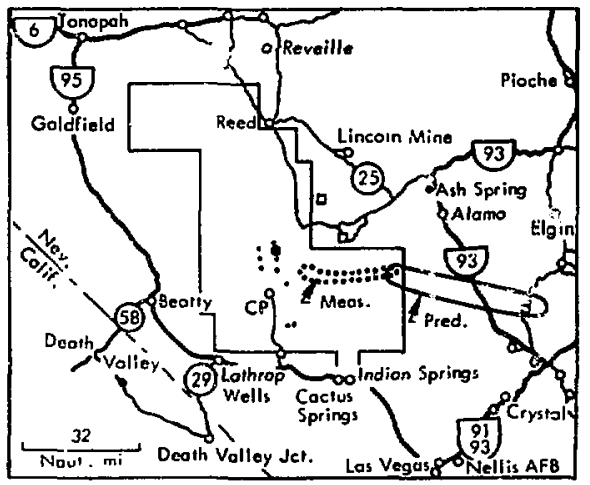

Fig. 4. Fallout from the Morgan shot fired on October 7, 1957, from a balloon at $500 \mathrm{ft}$. The solid line shows the predicted fallout pattern; the dotted line shows the actual fallout pattern. (From Ref. 2.)

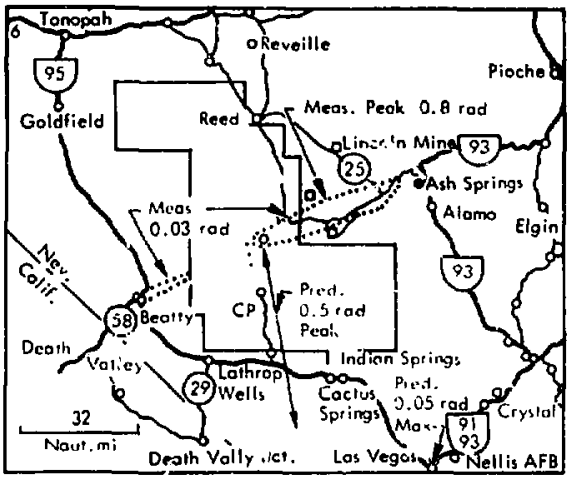

Fig. 5. Fallout from the Wilson shct firct on June 18,1957 . from a balloon at $500 \mathrm{ft}$. The solld line shows the predicted direction of ravel from the fallout; the dotted lines show the actual fallout pattern. (From Ref. 2.)

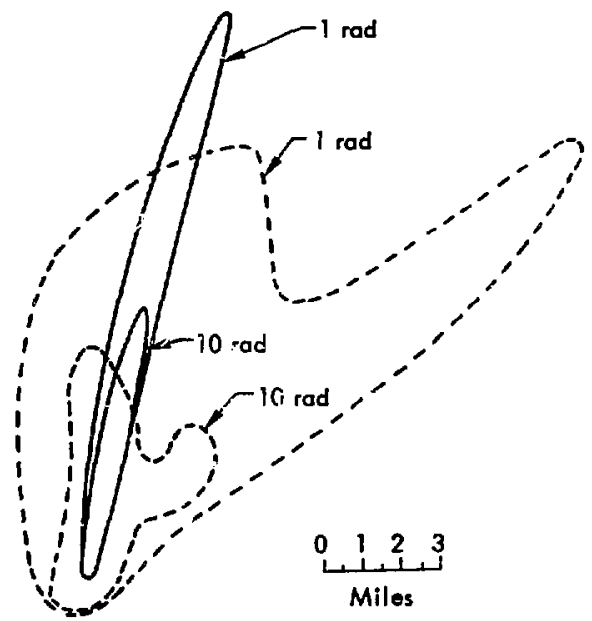

Fig. 6. Comparison of preshot prediction (solid lines) with observed fallout pattern (dotted lines) for the Schooner shot fired in 1968. (From Refs. 4. ad 5.) 


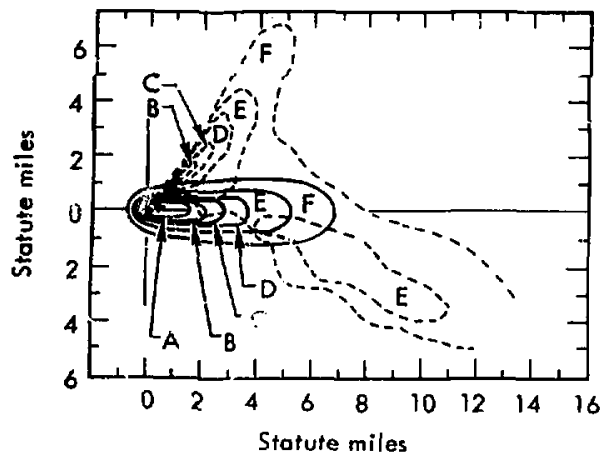

Fig. 7. Comparison of idealized model (solid lines) with actual fallout pattern (dotted lines) for a yield of $1 \mathrm{kt}$ and an effective wind of 10 knots. Dose rates in $R / h r$ at $\mathrm{H}+\mathrm{l} \mathrm{hr}$ were as follows: A-1B5. B-92, C-37, D-13.9, E-5. 1, F-14. (From Ref. 3.)

\section{CAUTIONARY REMARKS}

All through the literature on fallout, one finds that each new fallout prediction technique that is generated either takes into account the discrepancies of the former codes or is at least as good as the others but is much more efficient to use. One might conclude that prediction codes should be good enough to use as a subatitute for actual data.

Let us postpone judgement on whether fallout prediction techniques should be used for analysis beyond planning, until after some of the codes are described and their problems and consequences discussed. Until recent years, discussions of predictions of nuclear radiation effects would contain caveats to the reader, reminding him of the limitations of prediction schemes. Some of these warnings. ara worth restating here.
Glasstone's commencary on uncertainties in fallout predictions reads as follows:

Although the procedures ... for developing dealized fallout patterns under various conditions are probably as good as can be expected, it must be emphasized that they arc intended only for overall planning. There are several factors which will af."ect the covatis of the distribution of the early fallout and also the rate of decrease of the radioactivity. Near ground zero, activity induced by neutrons in $t^{\prime}$ e soil will be gigrificant, apas- from that due to the fallout. However, the extent of the induced activity is difficult to estimate, since it will depend on the type of weapon, e.g.. the actual amounts of fission and fusion energy, the heighi of burst, and the nature of the soil. The existence of unpredictable hot spots will also affect the local radiation intensity. These are dependent upon a variety of conditions not all of which are fully understood. The nature of the terrain may also influence the dose rat at a given location as a result 0 incidential shielding. The data is applicable to mocierately flat, uninhabited areas, such as those in which weapons tests rire carried out.

The rate of decay of the early fallout radioactivity, and hence the total dose accumulated over a period of time, will be affected by weathering. Wind may transfer the fallout from one location to another, thus causing local variations. Rain, on the other hand, may wash the fallout into the soil and this will tend to decrease the dose rate at a level a few feet above the ground. If rain should occur at the time of the detonation, the fallout pattern might be changed considerably.

In attempting to predict the time that must elapse, after a nuclear explosion, for the radiation dose rate to decrease to a level that will permit reentry of a city ... use may be made of the (continuous) decay curves. However, it is inadvisable to depend entirely on these estimates because of the uncertainties mentioned above. Moreover, even if the decay curve could be relied upon completely, which is by no 
means certain, the actual composition of the fallout is known to vary with distance from ground zero and the decay rate will vary accordingly.

From the text in general use containing the idealized fallout characteristic curves comes a disclaimer on the reliability of the data:

RELLABILITY. The degree to which wind and other meteorological conditions affect these contour parameters cannot be overemphasized. The contours presented in these curves have been idealized in order to make it possible to present average, representative values for planning purposes. Due to these limitations, a meaningful per centage reliability figure cannot be assigned to the idealized fallout pattern. Although the shape of the actual fallout contours cannot be predicted by this method, it nonetheless does provide a fair approximation of the total area affected, as well as identify the general downwind direction.?

The U.S. Army's field manual on fallout prediction makes the following statement:
RELIABILITY. The predicted zones of fallout are larger than the actual area on the ground that will be covered by fallout. These zones represent areas of hazard, somewhere within which fallout is predicted to be found. Because of uncertainties of weather and nuclear burst input data, the precise locations of fallout with in the zones cannot be reliably predicted but must be ascertained by monitoring and survey after fallout has settled. The zones, therefore, have been developed so that there is a reasonably high assurance that the expected fallout will not occur outside them. They represent an expected hazard area that can be quickly predicted immediately after nuclear burst information is obtained.

INTER PRETATION, The lines enclosing the fallout prediction are not to be construed as absolute boundaries for the occurrence of fallout. It is emphasized that as these predicted zones are approached from the outside, the likelihood of encountering hazardous fallout will increase and the dose rates encountered will gradually increase. Therefore, units would not normally be relocated based upon predicted fallout areas but, rather, upon actual radiological monitoring and survey information.

\section{Schemes for Fallout Prediction}

A large assortment of earlier computational schemes, both empirical and theor etical, were devised for preparing forecasts of fallout hazards. ${ }^{9}$ All of the models were similar in general features, yet they often gave dissimilar results. Prediction schemes in current use will be discussed here to indicate the present state of affairs.

\section{DELFIC}

Inconsistencies among the yarious prediction schemes prompted the Depart- ment of Defense in 1964 to begin developing a single, comprehensive fallout prediction model to serve as a standard for calibration of future models. The result was the formulation of a complex computer program called DELFIC (Defense Land Fallout Interpretive Code). ${ }^{10}$ However, its ability to be useful on a real-time basis as an aid in making prestrike and post-strike predictions, damage assessment studies, vulnerability analyses, and war-gaining plans is 
limited because it cannot cope with the information demand in tactical situations. Efforts have been made to produce more efficient mathematical modeling of the fallout process based upon lessoris learned from the DELFIC research model. ${ }^{11}$

\section{PROFET}

A group at the Nuclear Defense Laboratory derived a code called PROFET (PRediction Of Fallout at Early Time) ${ }^{12}$ from the DELFIC model. It runs on a UNIVAC 1108 with $48 \mathrm{k}$ words of memory. Minimum input data requirements are stabilized nuclear-cloud top and hottom heights and cloud width radius. The computer program features a wide assortment of output options to serve a variety of different interests. In addition to a set of map-generation routines to display exposure rate, total exposure, and timeof-arrival values, the program can provide an analysis of the fallout at any selected location. A maneuver dose option is included to provide a capability to estimate exposures received by parties moving through the radiation field.

It is claimed that the time requirements for using PROFET add up to $6 \mathrm{~min}$ to produce a usable result. This includes assemblage of input data, machine processing, and production of a map overlay.

Nine nuclear detonations were selected for comparison of prediction and observation. This sampling indicated that the program is capable of reproducing exposure-rate observations within a factor of 2 for $\mathrm{H}+1-\mathrm{hr}$ exposure rates above $20 \mathrm{R} / \mathrm{hr}$. The following caveat is contained in the report:
The extension of these concluaions to other situations can be justified only if the available weapon parameters and wind data exhibit at least the same degree of reliability as that which was used for the nine U.S. detonations cited. 13

\section{SEER}

Another fallout computational system derived from DELFIC is called SEER (Simplified Estimation of Exposure to Radiation) and was developed at Stanford Research Institute. ${ }^{14}$ The main purpose $o i$ th is development was to reduce computation time to $1 \%$ of DELFIC requirements. SEER runs on a CDC $6400 \mathrm{com}$ puter in 3 to $6 \mathrm{sec}$.

A comparison of the output from SEER with DELFIC and WSEG (Weapon System Evaluation Group of the Institute of Defense Analysis) models for a 1-Mt detonation with highly-gheared wind conditions is shown in Fig. $8 .^{15}$

The important parameters necessary for SEER input are clond top height, cloud bottom height (altitude abova sea level), cloud radius, and stabilization time.

Development of the model stems from the belief that

... models in current use cannot adequately predict fallout for the likely range of yield and wind conditions under which attack could occur, and the operational consequences of this inadequacy are significant. 16

\section{KDFOC}

Because the DELFIC was not designed to treat fallout from underground nuclear explosions, DNA requester that the Lawrence Livermore Laboratory supply a version of its KDFOC (K-Livision Fallout Code) $)^{17}$ for DNA use. 


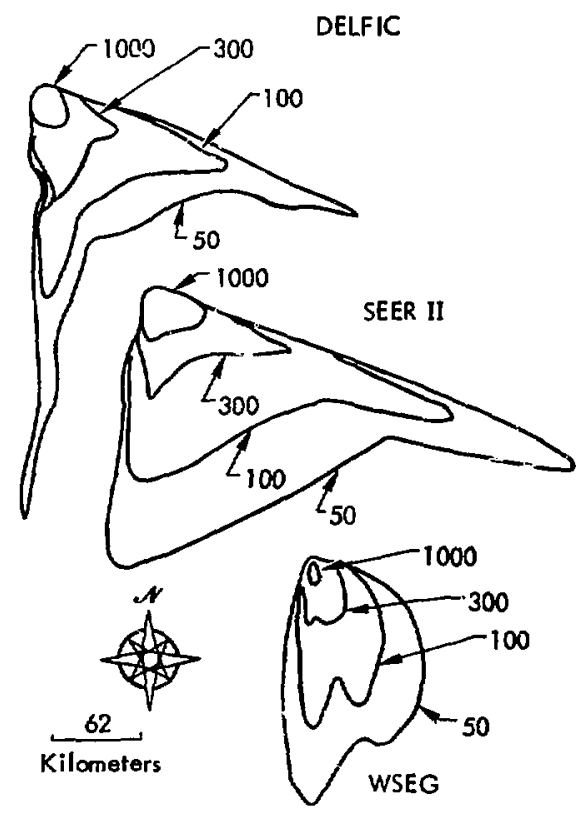

Fig. 8. Comparison of fallout patterns for a I-Mt detonation, (From Ref, 14.)

The code runs on a CDC 7600 computer. Its use is presently limited to the laboratory, and run time is not relevant.

Calculation of the fallout pattern for a nuclear explosion uses initial conditions concerning cloud stabilized geometries, their activity/particle-size distribution, and the wind field that transports and deforms the clouds.

Nine test detonations were chosen to compare with KDFOC for code verification. Values for all input parameters were found except for particle-size description. Repetitive problems were run, with varying particle size input, until the fallout pattern produced by the code satisfrictorily matched the observed fallout pattern for a partlcular shot. A sample of the reasonableness of fit for a surface burst is shown in Fig. 9 with dose rates along the "hot line" used as a gauge.

WEDS

A prototype display oystem containing a fallout prediction code, as well as prompt effects, was built by $X$-Divlsion of the Luwrence Livermore Laboratory and is known as WEDS (Weapons Effects Display System). 18,19 It fulfills the need for a portable, instantaneous, visuai display of fallout. A Varian $620 / 1 \mathrm{mini}$ computer is used for computation.

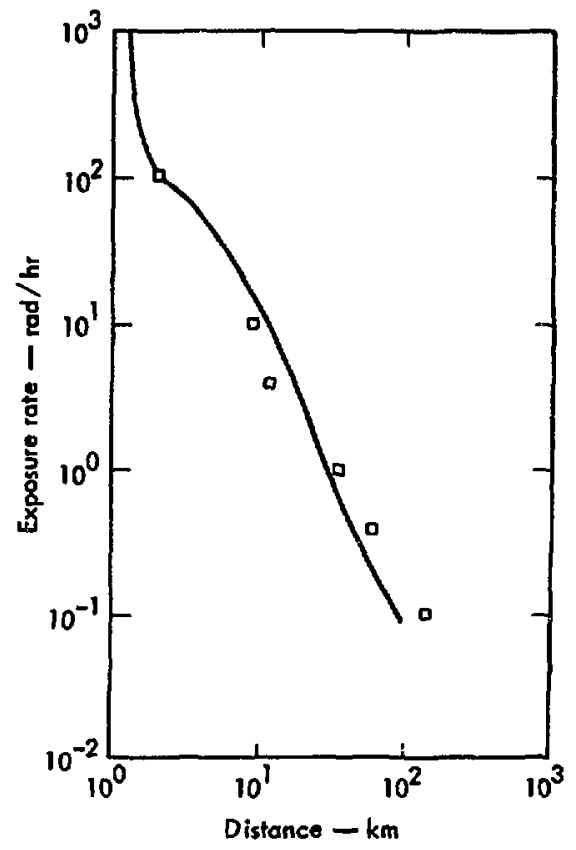

Fig. 9. KDFOC calculated (data pounts) and observed (solid line) exposure rates along the "hot line" for the Johnnie Boy shot. (From Ref. 17.) 
Figure 10 shows an outline drawing of the WEDS MOD II console.

The fallowit siodel used 18 derived from a mathematical model ${ }^{20}$ developed by A. D. Anderson of the Naval Radiological Defense Laboratory. Rather broad assumptions are made to produce a simple but realistic model that is capable of giving fix'st-order approximations. The major assumptions are a hat earth, reactions with typical soils, and uniform, nonturbulent winds. Input parameters are yield, wind, and soll conditions. Army fallout prediction patterms can also be generated.

\section{U.S. ARMY FALLCUT MODẼL}

The U.S. Army uses a handcalculation motel ${ }^{8}$ that describes fallout in two zones (Fig. 11). The - ficted zone" define those areas within which exposed, unprotected personnel may receive militarily significant total doses of nuclear radiation within 1 to $4 \mathrm{hr}$ after arrival of fallout.

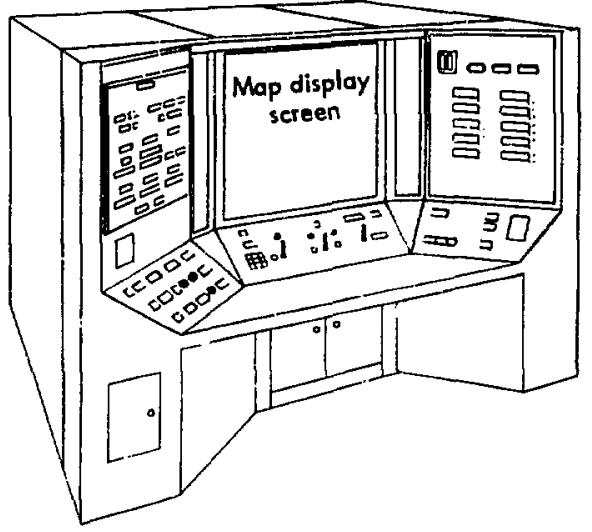

Fig. 10. WEDS MOD $\amalg$ console.

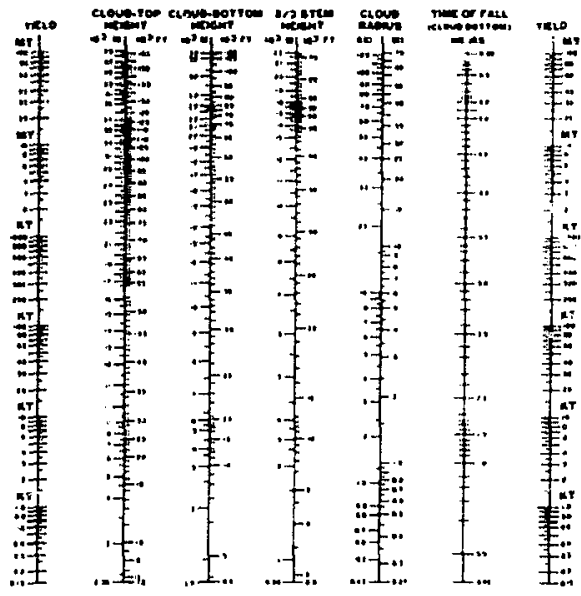

Fig. 12. Radioactive cloud and stem parameters (stabilized at H+10 min). (From Ref. 8.)

An overlay is prepared by using nomographs, one $\%$ the weapon yield is determined from radioactive cloud and stem parameters as given in Fig. 1i. ${ }^{21}$ 
The cloud chart is used af a sliding-scale nomograph, and all parameters are expected to line up for a given yield.

Nomographs are available 22 to aide in calculation of ivis! Jose acquired in contaminated areas. Detalled prestrike fallout predictions can bo prepared for "(riendly" nuclear bursts by using provisions for adjustments for height-of-burst and fission/yield ratios less than 1.

\section{NRDL D-MODEL}

It was the contention of the Naval Radiological Defense Laboratory ${ }^{23}$ that the Army (TM3-210) and Navy (ATP-25) models provide their users with roughly equivalent information, but that information is not necessarily accurate. NRDL went on to develop their own computer model called the NRDL Dynamic Fallout Model.

The NRDL D-Model is derived from Anderson's earlier model, ${ }^{20}$ where the geometry of the radioactive cloud is approximated by a right circular cylinder. Some of the initial limitations such as turbulenee, time, and space variation of the winds aloft and circulation within the cloud were accounted for in the later computer codes. 24

The cylinder is sliced horizontally into a number of wafers. The wafers move vertically and horizontally under the influence of the rising and expanding cloud, gravity, and the winds at various altitudes.

Justification given for accepting the D-Model as a valid standard of comparison comes from 1) ine attention it pays to the details of the synamice of cloud behavior and 2 ) the $f i$. of the cloud dimensionsversus-yield curve to the test data, which is claimed to be a better fit than the Army or Navy curves provide.

NRDL modified the Army model to bring it into conformance with their results (Figs. 13a and b). NRDL then went even farther and revised the Army model by adding some of the characteristics of the $D$-Model (Figs. 13c and d), on the assumption that the D-Model should be used as the standard model for fallout prediction.

\section{UNCERTAINTIES}

All of the preceding fallout prediction schemes, as well as any that may be generated in the future, suffer from the inability to totally describe the environment and the interaction a nuclear detonation may have with it. The results of any simulation are, of course, only as good as the model used to describe the phenomena being studied.

The DELFIC code represents the most complexity that can be tolerated in a fallout computer code. Evidently, it has been judged too difficult to use in operational situations. The creation of SEER represents a step toward simplification of prediction techniques. The uncertainties that are not now accounted for in prediction will continue to be with us. These include

1) wind-field description,

2) wind variability (dynamic modeling),

3) terrain interaction and irreguiarities,

4) fractionation,

5) rainout,

6) hot spots,

7) cloud-parameter measurement and interpretation. 


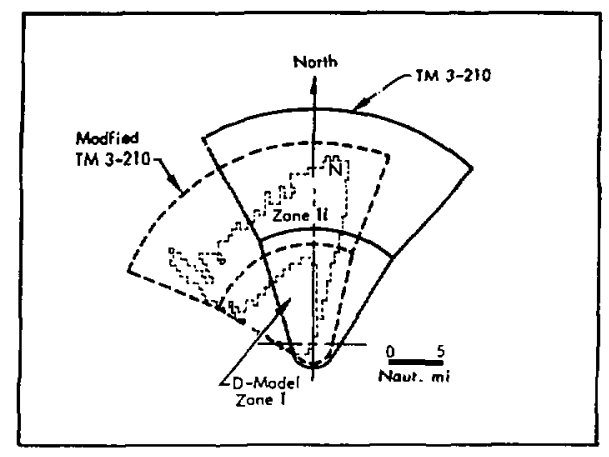

(a)

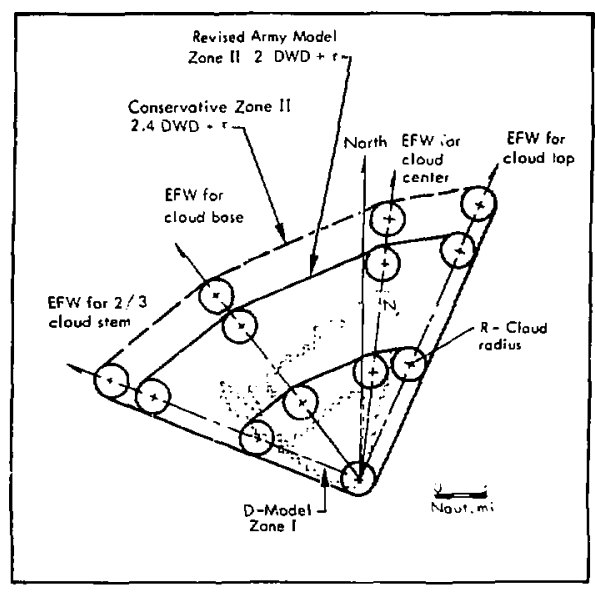

\{c\}

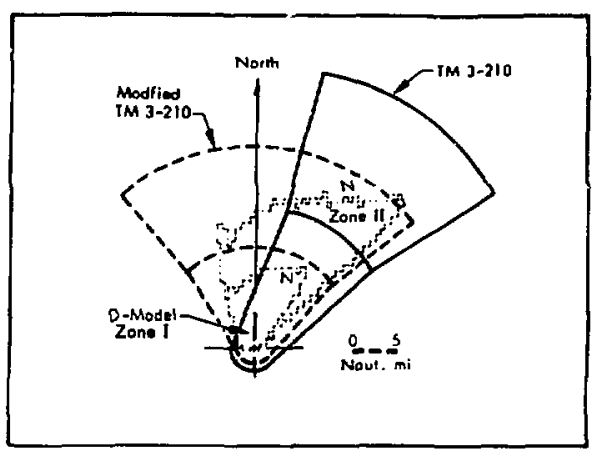

(b)

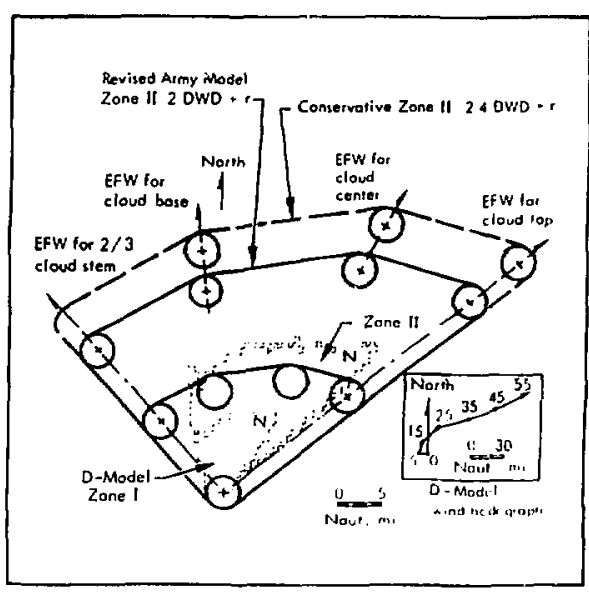

(d)

Fig. 13. NRDL modifications to a) the Army model for $10 \mathrm{kt}$, and b) the Army model for $50 \mathrm{kt}$. Characteristics of the D-Model are added to the Army model in c) for $10 \mathrm{kt}$ and in d) for $50 \mathrm{kt}$. (From Ref. 23.)

\section{Areas of Particular Uncertainty}

WIND

The general method of modeling winds has been to divide the nuclear cloud into
11 to 13 "wafers" with the last known wind data assigned to each altitude. With a fairly stationary situation, this produces suitable results most of the time. 
However, when meteorological conditions are unstable, the effects of variations in wind speed, angslar displacement (shear), and vertical components will produce unpredictable results. The problem of accounting for these conditions is threefold: 1) modeling the effects accurately, 2) accuracy of weather l'eports, and 3) acquisition of current conditions.

One of the difficulties in solving these problems entails generating a new prediction model to account for the above wind-parameter variations that would necessarily make that model much more complex than the DELFIC. The problem of ensuring that the data received are accurate delves into human factors versus automation. The last problem (keeping current) pertains not only to the ability to make frequent measurements but also to digesting and operating on the data dynamically.

\section{TERRAIN}

Terrain factors include soil types, soil conditions, surface contours, vegetation, and mountainous regions. One reason that computer codes can be verified so well with observed data from nuclear detonations is that repetitive runs can be made with varying parameters assigned to cloud debris until an appropriate mix produces a satisfactory match. This hindsight would probably not be available at a particular time and place when a future conflict may produce a nuclear detonation.

The Naval Radiological Defense Laboratory studied the effect of structures and terrain contours on radiation patterns. ${ }^{25}$ A square grid pattern such as shown in F.g. 14(a) was used as a standard. Fall- out was assumed to descend uniformly onto the pattern. The effect of slopes and ravines and of follage and shelters on the settlement of radioactive particles was calculated on a computer. The radiation at any location due to this disiribution of fallout could then be determined. The results are shown in Fig. 14(b), where relative dose is plotted as a function of the ground altitude at the detector.

Since the study used idealized conditions, its results cannot be verified. We have found no further work that applies tersain conditions to modify any fallout prediction scheme. There is some question as to the value of pureuing this, in light of the complexities as well as the possibly low potentlal for verification of results.

Some investigations of ground-roughness effects have been carried out, although these are limited; there have been only six measurements of ground roughness in real fallout aituations. ${ }^{26}$ An NRDL report points out some of the measurement difficulties attributable to terrain nonuniformity. ${ }^{27}$ One mair. complication arises from the fact that measurements are taken at a height of $1 \mathrm{~m}$ above the ground. The absorption of a meter thickness of air is equivalent to approximately a millimeter of soil material. At least fcur models have been identified and compared, ${ }^{28}$ with the conclusions that the simplest model (buriedsource) is adequate to predict gross effects.

Other studies have examined the effects of microrelief, 29,30 which is a larger variation in the terrain than the microstructure considered by the term "ground roughness." It was found that, in general, microrelief reduces the $\gamma$-ray intensity from fallout products. The radioactive isotopes gradually penetrate the soil. When 


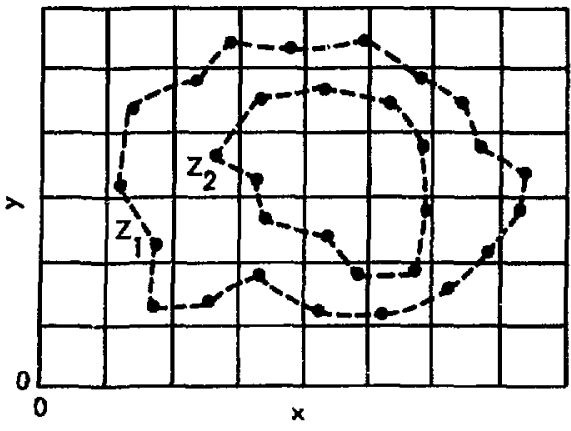

(a)

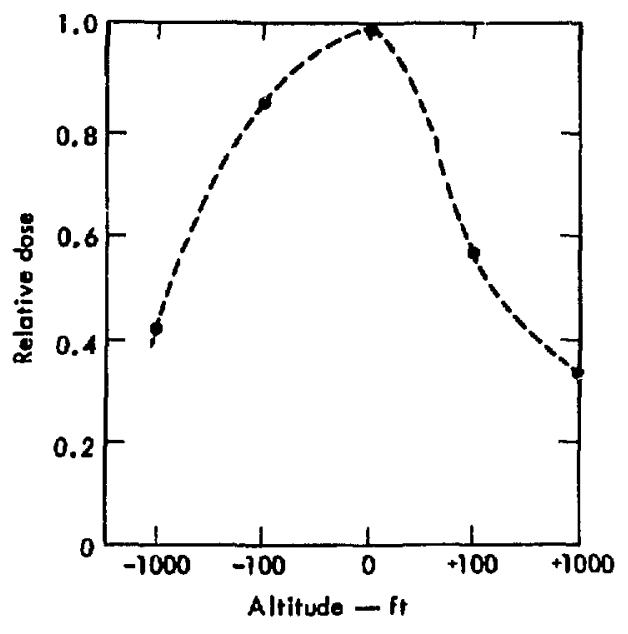

(b)

Fig. 14. a) Example of grid and terrain contours $\left(Z_{1}\right.$ and $z_{2}$ are elevation contours). b) Relative dose versus terrain eltitude. (From Ref. 25.)

uniform contamination of the soil reaches a depth exceeding several mean-free paths for the $\boldsymbol{\gamma}$ quanta, the effect of microrelief practically disappears.

A cloud can also interact with mountains, and prediction schemes have yet to take this into account. An example of this is shown in Fig. 15, where the Teapot shot fallout debris was shaded by a nearby ridge. The effect of the mountain on the prevailing winds most probably played a part in shaping the pattern, too.

The above concerns deal with determinating the interaction of the earth with a nuclear weapon detonation. As an aside, the USSR stresses consideration of the ability of troops on the battlefield to use the terrain in reducing the radiation hazard to them. 31

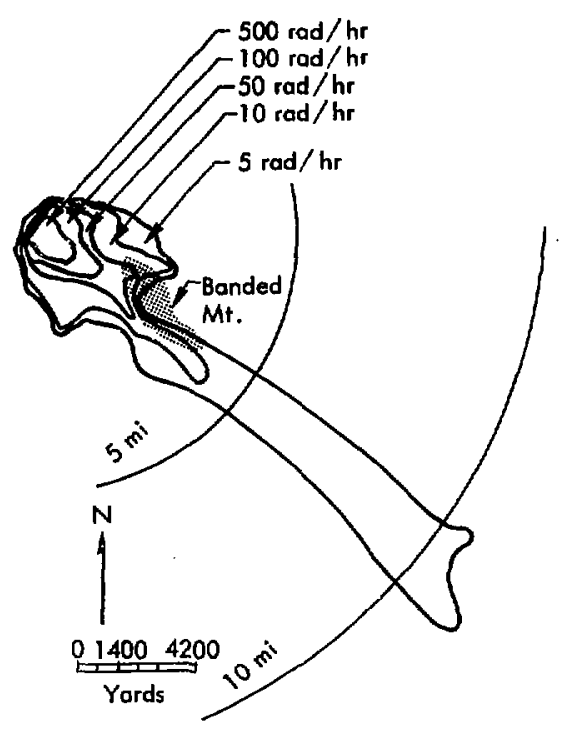

Fig. 15. Failout pattern for Teapot shot at $\mathrm{H}+1 \mathrm{hr}$. 


\section{MAGIC NUMBER}

A critical parameter used in predicting nuclear fallout is the estimation of the dose rate caused by spreading the fission products of $1 \mathrm{kt}$ of material over a $1-8 \mathrm{q} \mathrm{ml}$ area on an infinite plain at $\mathrm{l} \mathrm{hr}$ after detonation. This was originally estimated to be $1200 \mathrm{R} / \mathrm{hr} / \mathrm{kt} / \mathrm{sg} \mathrm{mi}$ and came to be known as the "magic number." This waa later revised to 3050 in the 1962 edition of The Effects of Nuclear Weapons. Both of these numbers were challenged by RAND ${ }^{32}$ when they analyzed the Buster Jangle surface shot of Navember 1951.

The actual number is affected strongly by fractionation, which is th: tendency of certain isotopes to condense or solidify early into larger particles that fall to earth sooner than other isotopes. This, then, affects the percentage of radioactivity down on the ground at any given time. RAND made a case for using the magic number 900. The controversy, incidently, is still not over.

\section{RAINOUT}

Very little has been written about rainout since Glasstone first cautioned the scientific community about it, ${ }^{6}$ but recent iterature ${ }^{33,34}$ indicates the extent of its possible consequences. Prior statements about the conduct of nuclear warfare assumed that "friendly forces" would detonate their weapons as air bursts, thus avoiding fallout, However, rainout possibilities were neglected, and the studies in Refs. 34 and 35 have shown that rainout could have lethal resulto beyond $100 \mathrm{~km}$ from ground zerc The results of these investigations are lopicted in Fig. 16.

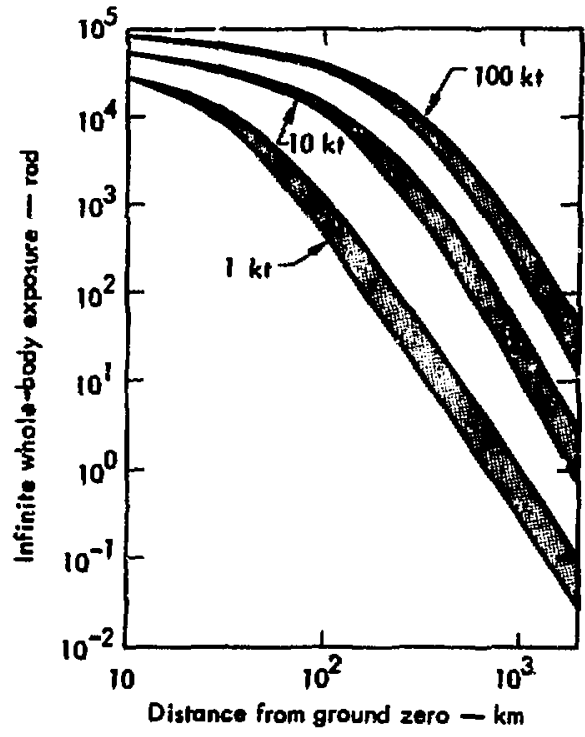

Fig. 16, Vertical integral (infinite whole-body exposure) due to grose $\gamma$ radiation as a function of distance from ground zero. The upper curve for each yield represents the case of slow horizontal diffusion; the lower curve represents the case of fast diffusion. (From Ref. 33.)

Figure 16 indicates the vertical integral, which is the amount of radiation debris that could be scavenged if rainout were to occur down through the entire cloud. However, Table 1 (from Ref. 34) shows that, as the yield goes up, the dose experienced on the ground could decrease. This is so because debris from largeryteld devices is projected above the usual level of rainclouds. Thus, only a fraction of the radioactive particles can then be scavenged. This can be readily seen in Fig. 17.

Some studies are now in progress to determine the feasibility of rendering the 


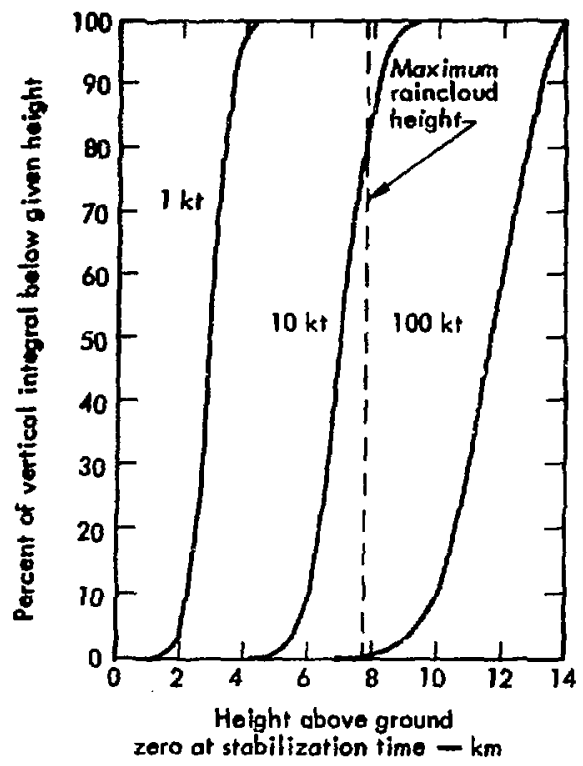

Fig. 17. Fraction of the vertical integral lying below a given height in the atmosphere. (From Ref. 33.)

debria particles nonwettable, thereby congiderably diminishing the rainout coefficient.

\section{CLOUD PARAMETERS}

The most important data necessary for making predictions of fallout are weapon

Table 1. Potential surface exposure and downstream exposure rates.

\begin{tabular}{|c|c|c|c|c|}
\hline $\begin{array}{c}\text { i icld } \\
(k 1)\end{array}$ & $\begin{array}{c}\text { Framticm } \\
\text { depusited } \\
(\%)\end{array}$ & $\begin{array}{c}\text { Distante } \\
\text { downwind } \\
(k n+1)\end{array}$ & $\begin{array}{l}\text { Infiicile } \\
\text { whole-bendy } \\
\text { oxturnaly } \\
\text { dose } \\
\text { (ront) }\end{array}$ & $\begin{array}{l}\text { External y } \\
\text { rxposure: } \\
\text { rate at } \\
\text { timo of } \\
\text { arrival } \\
\text { (IR hr }\end{array}$ \\
\hline 1 & 100 & $\begin{array}{r}10 \\
100\end{array}$ & $\begin{array}{r}25,000 \\
400-1200\end{array}$ & $\begin{array}{l}25,900 \\
35-100\end{array}$ \\
\hline 10 & 10 & $\begin{array}{r}10 \\
100\end{array}$ & $\begin{array}{r}5000 \\
1000-1500\end{array}$ & $\begin{array}{r}7000 \\
1.50-200\end{array}$ \\
\hline 100 & 1 & $\begin{array}{r}10 \\
100\end{array}$ & $\begin{array}{r}300 \\
30 \mathrm{~J}-350\end{array}$ & $\begin{array}{r}12100 \\
45-65\end{array}$ \\
\hline
\end{tabular}

yields. For "friendly" detonations, we assume that this information is avallable at "friendly" headquarters. For "enemy" bursts, we assume that yield information can be derived from nuclear cloud parameters. It is worth examining here the variability in results that may be obtained from cloud measurements.

One question that arises immedlately is, how much tolerance is there in the tranglation of cloud parameters to yleld? Secondly, how well cart and will these parameters be measured in the field?

\section{Tolerance}

The basic relationstips amorg cloud maximum and minimum heights determined by DELFIC, the U.S. Army method, and observation are shown in Fig. 18 (see also Ref. 35). All other codes use relationships that are between the DELFIC and Army levels. The curves change slope at about the 10-kt level because of the interaction of the cloud with the tre jopause, which acts to suppress the deiris. The level of the tropopause is very dependent upon the latitude and time of year as well as on the gross meteorological conditions at the time,

Figure 18 shows the wide dispersions in results that can be obtained from cloud measurements. For example, if the cloud base height were $15,000 \mathrm{ft}$, the yield could range from $1.5 \mathrm{kt}$ to $100 \mathrm{kt}$. The Army would consider the yie!d to be $5 \mathrm{kt}$, and DELFIC would interpret it to be $40 \mathrm{kt}$. For a cloud top height of $25,000 \mathrm{ft}$, the range could be from $s \mathrm{kt}$ to $40 \mathrm{kt}$, with the Army's resultant yield calculated to be $5 \mathrm{kt}$ and DELFIC choosing $20 \mathrm{kt}$. Other altirudes give similar discrepancies. 


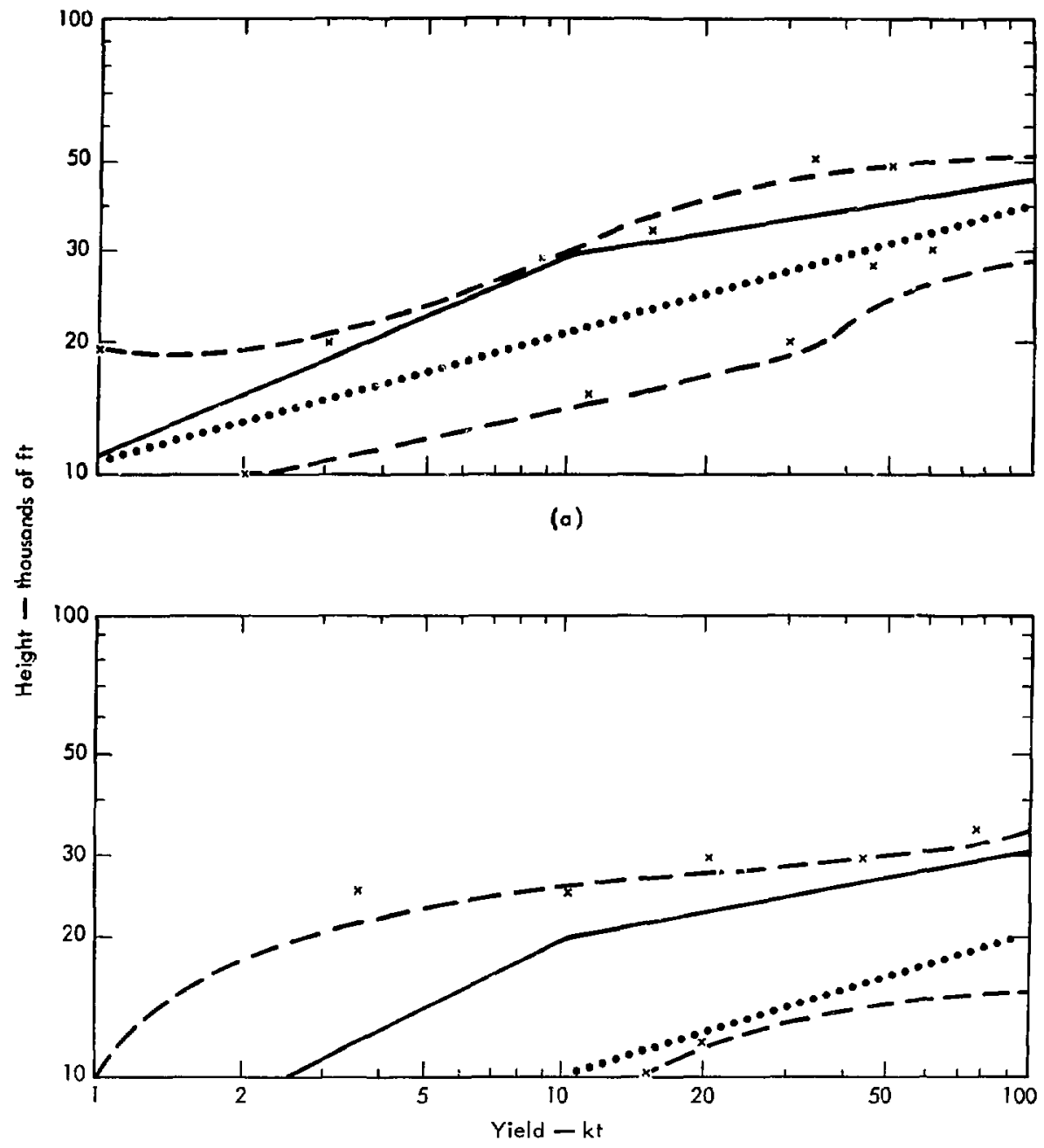

(b)

Fig. 18. Relationships among a) cloud top and b) cloud bottom heights for various yields, determined by three methods. Dotted lines: DELFIC (from DNA 3008F); solid lines: U. S. Army plot (from TM 3-210); dashed lines: observed (from UCRL- 51179).

Measurement

While many of the cloud measurements at nuclear tests were made with photo- graphs, most were accomplished with theodolites. ${ }^{36}$ Photography could not be used in a battlefield operation, which 
requires rapid responses, and there is some question as to whether theodolites can be set up and used spontaneously as required in a battle.

Some investigations hav' been carried out to determine whether lasers would be helpful in this area. ${ }^{36-39}$ There is also some question about the ability to operate such a device in the field. There has been some consideration of using Lidar in satellites, ${ }^{39}$ but we do not know the status of that proposal.

An airborne radar system has been develcped to detect and delineate nuclear clouds so that aircraft could be directed into the proper position to launch ballistic sampling rockets into the clouds of nuclear tests. The LAPO-1 system 40 was designed to satisfy the test diagnostics requirements of the National Readiness Prograrr' 's Cleansweep project. There is an inherent need for a continuous readyalert when aircraft are used, since the measurements of interest come from clouds that have stabilized $10 \mathrm{~m}$ in after detonation.

The crude forearm-and-thumb method of congruent triangle estimation by field soldiers may remain the only way that these cloud measurements can be taken. An indirec: commentary on visual observation by the Wori.: Meteorological Organization is very apropos here:

The ability to estimate cloud-base heights satisfactorily can be acquired only by long experience and observers should take every opportunity of checking their estimates by comparison with instrumental meas urements. Cloud-base heights are sometimes indicated by the fact that the tops of hills of known heights are obscured by cloud. Evidence of this sort, however, is not usually reliable at distances from the observer greater than about five kilometers. There is a special need for a high degree of skill and experience in making acceptable observations in flat areas. Little reliance can be placed on night visual observations... The height of clouds above three k llometers cannot be estimated satisfactorily. 41

\section{Consequences}

Although study during Project Oregon Trail indicated potentfal applications of fallout in combat situations, ${ }^{42}$ there is currentìy no known consideration for purposefully producing fallout from any "friendly" nuclear detonation. This trend of thought is expected to continue. This does not deny, however, the possibility of error. But of more concern than that is the possibility of an enemy burst that we are not prepared to cope with.

Disconcerting collateral damage effecis in the civilian hazard areas may accrue from the use of tactical nuclear weapons, ${ }^{43}$ which causes doubts of military effectivenuss. Shortcomings of some nuclear weapons may make advance planning operationally impractical and politically questionable. These concerns derive not only from the initial, local effects of nuclear weapons on a populated battlefield, but also from more widespread effects caused by fallout and rainout.

The military planners in the days of Oregon Trail placed implicit trust in the fallout-prediction techniques. Trust in these prediction codes was a necessary part of the recommendations that 
were made then. Uncertainties in using the prediction schemes weigh heavily on military commanders, however; hence the doctrinal statement repeated at the beginning of this report, ${ }^{8}$ in which the current field manual cautions against committing troops to action based upon prediction results.

One way to look at the consequences of incorrectly predicting fallout on a battlefield would be to examine the delay in maneuvering through the area of interest. A nominal rate of a daytime cross-country march is $1 \frac{1}{2} \mathrm{mph}, 44$ and night marches are normally at $1 \mathrm{mph}$. The Nuclear Radiation Degree-of-Risk Exposure Criteria ${ }^{45}$ for troop safety are given in Table 2. The idealized fallout patterns as given by the Defer:se Nuclear Agency (Ref. 3) can be used as a guide to determine the delay required before a commander commits his troops to an area. A number of examples are illustrated in Figs. 19, 20, and 21 (see the Appendix for calculations used to produce the delays shown), which depict fallout zones within the $10 \mathrm{rad} / \mathrm{hr}$ isodose contours and are arranged in three categories of risk for combat troops with 85 rad previous exposure): negligible, moderate, and emergency. For march rates of $2 \mathrm{mph}$ and $1 \mathrm{mph}$, the amount of time delay before an area could be entered (to hold radiation doses below the ranges given) is stated for various distances from ground zero.

It can easily be seen that a mistake in judgment of yield can produce substantially different delays. For example, if combat units desired to cross a contaminated area $10 \mathrm{mi}$ from ground zero at $2 \mathrm{mph}$ and they understood it to be affected by a 100-kt burst, they would wait 4
Table 2. Nuclear radiation degree-ofrisk exposure criteria. ${ }^{a}$

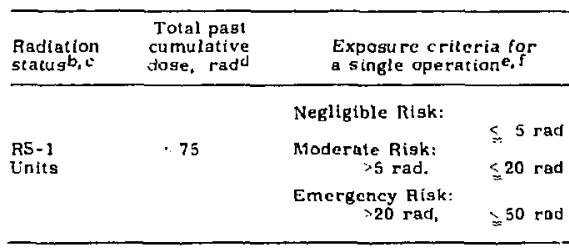

\begin{tabular}{|c|c|c|c|}
\hline \multirow[b]{2}{*}{$\begin{array}{l}\text { RS-2 } \\
\text { Units }\end{array}$} & \multirow[b]{2}{*}{$75-150$} & \multicolumn{2}{|c|}{$\begin{array}{l}\text { All further exposure can- } \\
\text { sidered Moderate or } \\
\text { Emergency Risk. } \\
\text { Moderate Risk: }\end{array}$} \\
\hline & & $\begin{array}{l}\text { Moderate Risk: } \\
\text { Emergency Rlsk: } \\
>5 \text { rad. }\end{array}$ & $\begin{array}{l}\leqq 5 \mathrm{rad} \\
\leqq 20 \mathrm{rad}\end{array}$ \\
\hline $\begin{array}{l}\text { RS-3 } \\
\text { Enits }\end{array}$ & $\begin{array}{l}\text { >1sr: } \\
\text { (Threshold for } \\
\text { onset of combat } \\
\text { ineffectiveness) }\end{array}$ & \multicolumn{2}{|c|}{$\begin{array}{l}\text { All durther expasure con- } \\
\text { gidered Emergency Risk. }\end{array}$} \\
\hline
\end{tabular}

\footnotetext{
SSee Ret. 3,

${ }^{b}$ Radiation status categories are bescd on previoug exposure to radiation.

'Reclasslfication of units from one radiation status category to a less serious one is done by the commander upon advice of the surgeon after ample observation of actusl state of health of the exposed personnel has been made.

All exposures to radiation are considered to be total body and simply additive. No bllowance is made for body recovery from radiation injury.

The operation exposure guide established by the commander can be any number in the risk range appropriate to the unit's mission and radiation status and includes exposure to all predictable initial and residual radiation.

$f_{\text {Risk levels are graduated within each status category in }}$ order to provide more stringent criteria as the total radiation dose aceumulated becames more serious.
}

days until the radioactivity decayed to such a level that the total dose received would be negligible ( $55 \mathrm{rad}$ ). If it was determined that an emergency risk were warranted, they would sti!l have to wait for a day before entry. But if the yield were actually $10 \mathrm{kt}$, only $3 \mathrm{hr}$ delay would be necessary to assume a negligible risk and none if a moderate risk were acceptable.

Converseiy, if the yield were actually $100 \mathrm{kt}$ and judged to be $10 \mathrm{kt}$, the troops committed to the area after $3 \mathrm{hr}$ would probably be fatalities. The variations in debriscloud top and bottom heights shown in Fig. 18 are of such wide latitude that an orderof-magnitude mistake in yield could occur. 

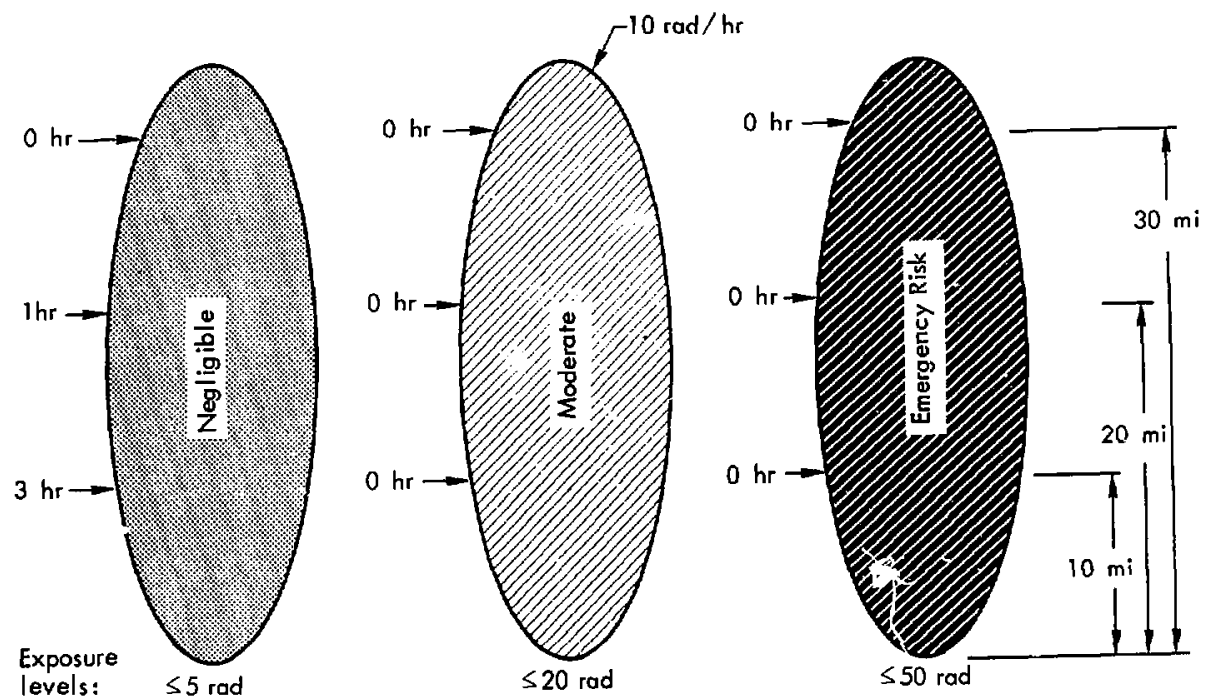

March rate $-2 \mathrm{mph}$
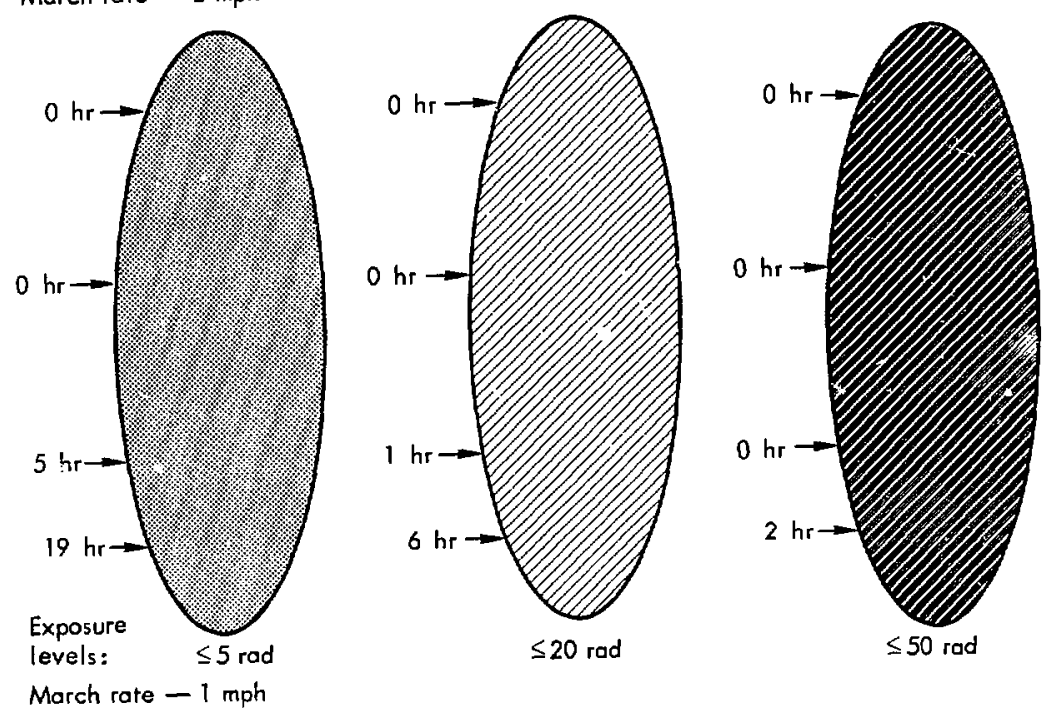

Fig. 19. Entry delay to $\gamma$ radioactive areas, following a 10-kt detonation. 

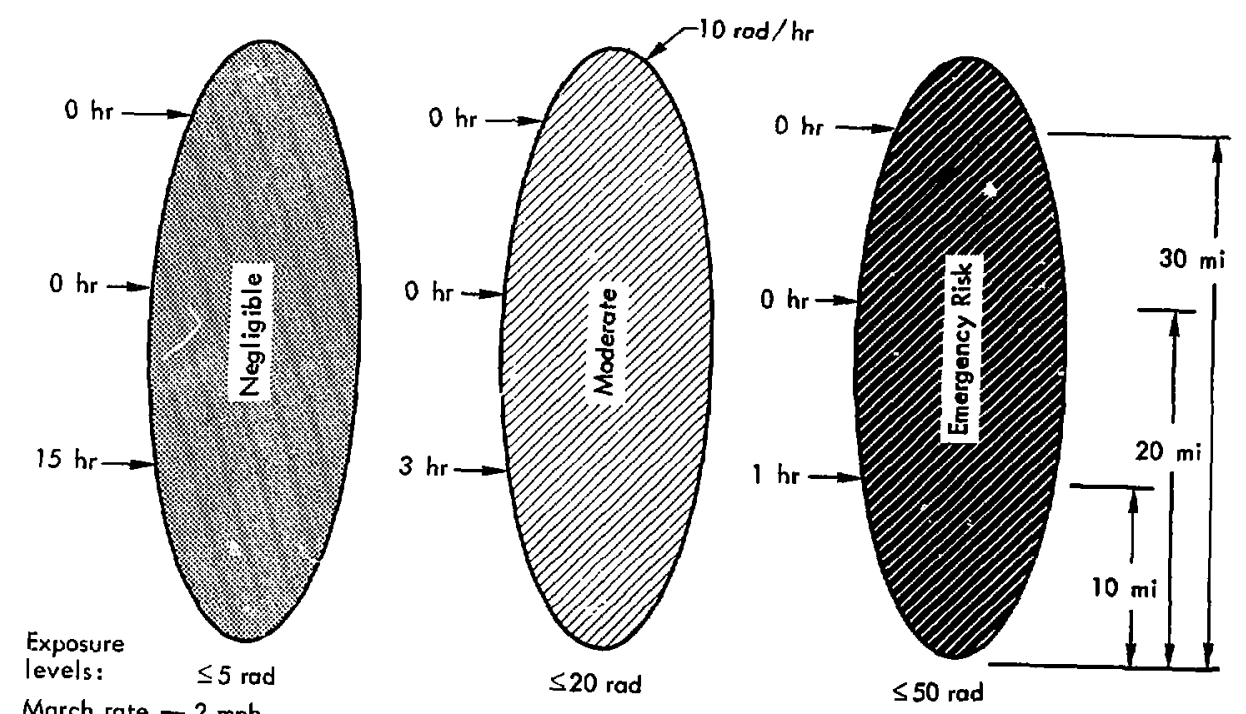

March rate $-2 \mathrm{mph}$
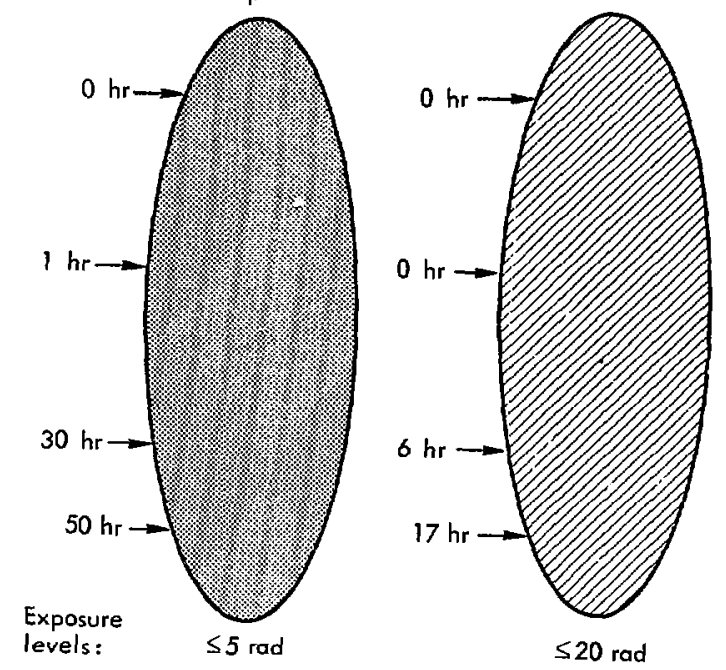

March rote $-1 \mathrm{mph}$

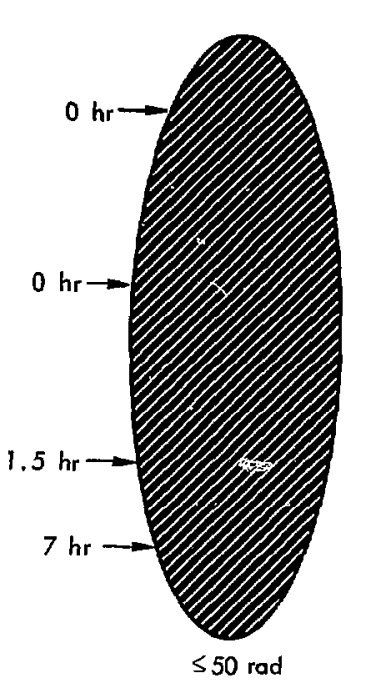

Fig. 20. Entry delay to $\gamma$ radioactive areas, following a 20-kt detonation. 

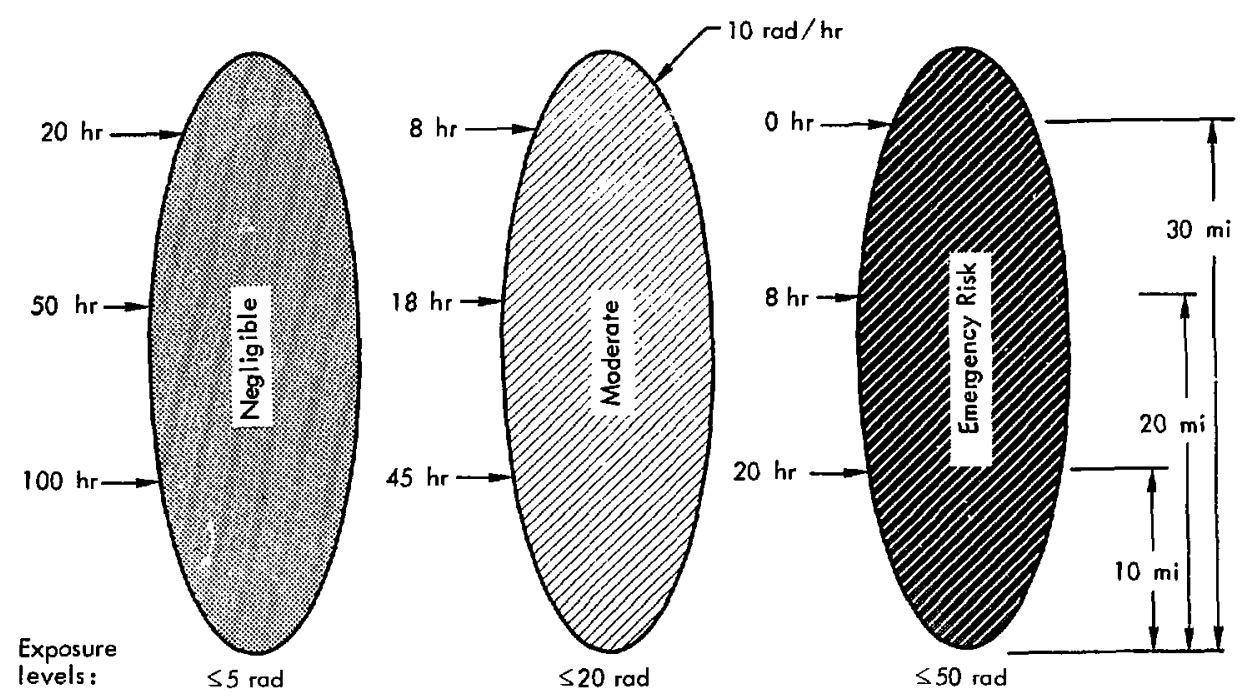

March rate $-2 \mathrm{mph}$
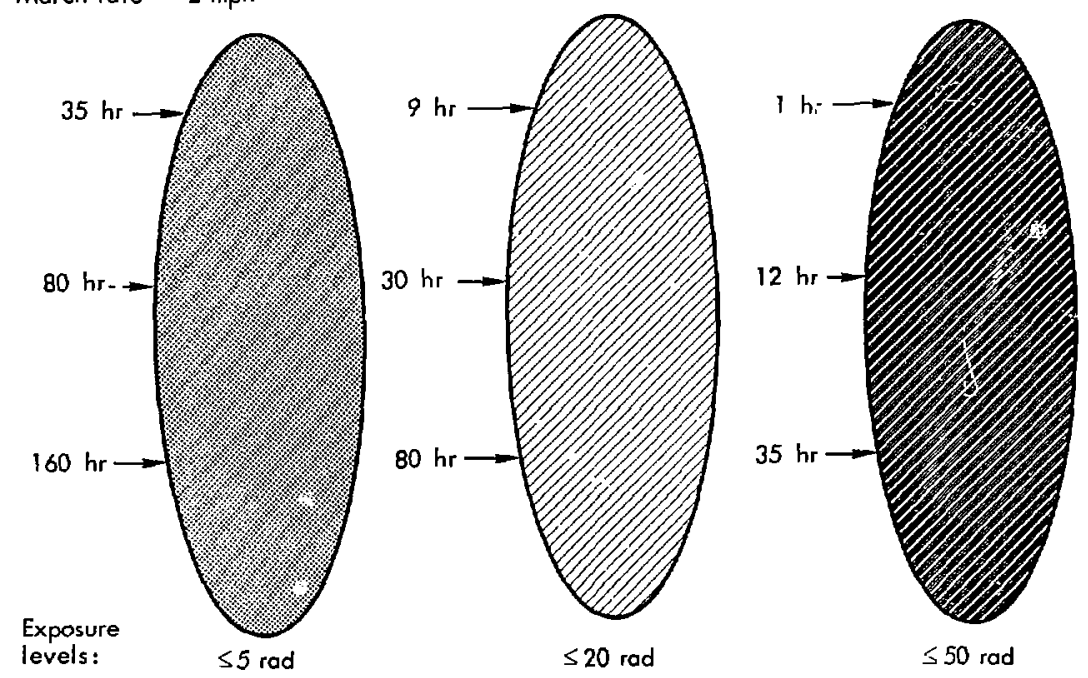

March rate $-1 \mathrm{mph}$

Fig. 21. Entry delay to $\gamma$ radioactive areas, following a 100-kt detonation. 


\section{Recommendations}

Until such time that real-time radiation data can be made available to the field commander, prediction information must be used. Each prediction scheme depends upon yield information, which is derived from debris-cloud characteristics

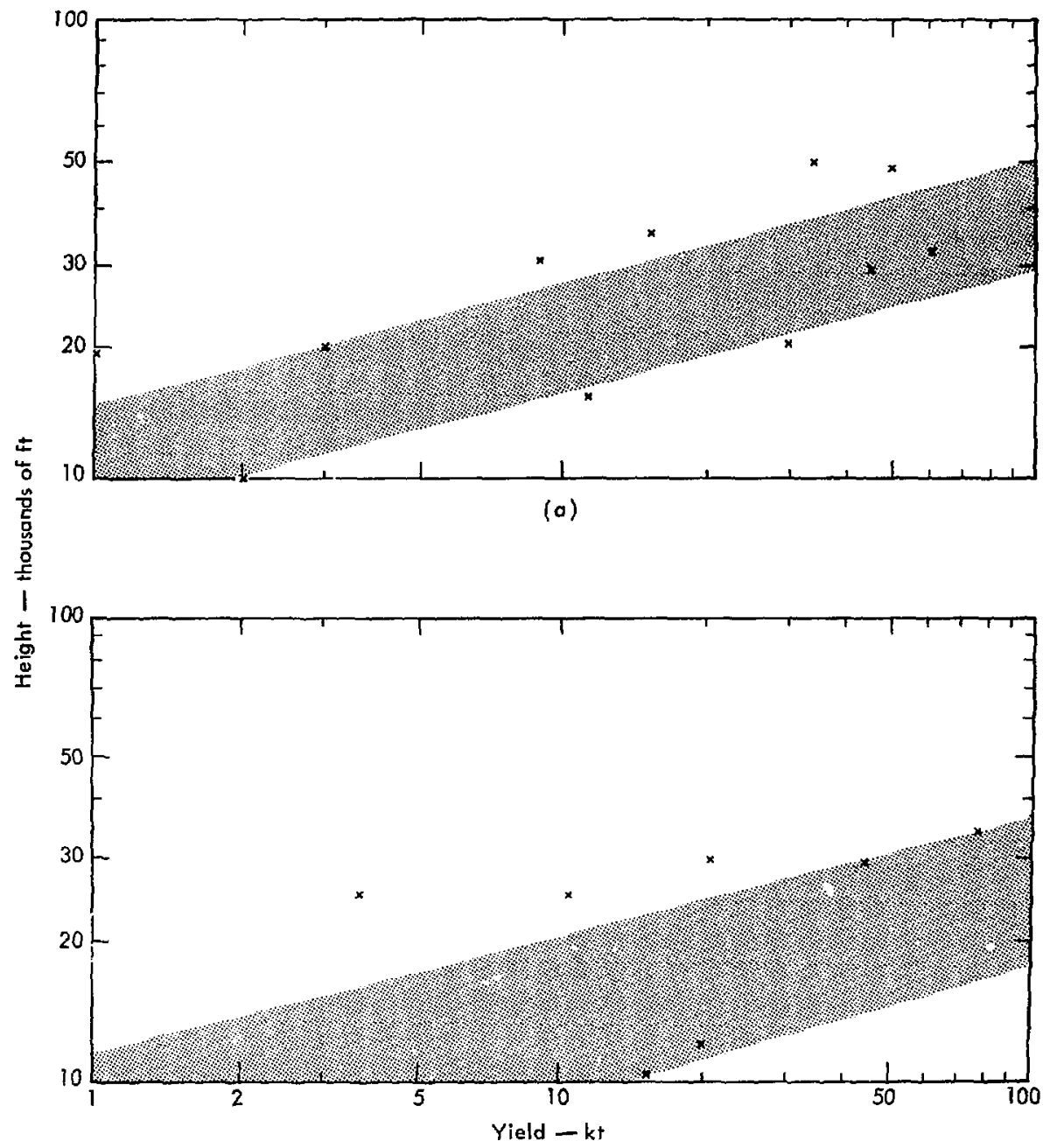

(b)

Fig. 22. Bands if yields possible (range extends from minimum to maximum) for given heights of a) cloud tops and b) cloud bases. 
if the burst were from an enemy weapon. So far, every organization originating a new prediction scheme has chosen its own "best-fit" curve to match the cloud data. Even yields derived from weapon EMP (electromagnetic pulse) and optical signatures have been described as singlevalue runctions, disregarding the orderof-magnitude variation in these effects.

Instead of depending upon a characteristic determined by any disputed line drawn through the region of data points, perhaps commanders should be presented with upper and lower limits to risks. An example of how to do this would be to define a "band" of yields possible for given measurements, as shown in Fig. 22. Rather than use data with a low confidence level, headquarters personnel could operate on a set of limits describing bounds to the radiation hazards that may exist.

For example, if cloud estimates were given as 20,000 ft for the top height and $18,000 \mathrm{ft}$ for the base, the range of posstble yields producing such a result could be $3 \mathrm{kt}$ to $30 \mathrm{kt}$ (resolving top and base data ranges). If an "idealized" fallout pattern were assumed, troops were $10 \mathrm{mi}$ from ground zero, a moderate risk were warranted, and movement could proceed at $1 \mathrm{mph}$ through the fallout zone, then a wait period of less than $1 \mathrm{hr}$ at a minimum and no more than approximately $10 \mathrm{hr}$ at a maximum would be required. With this knowledge the commander could consider the possible maneuvers until hard data arrived.

If he wanted to play safe and a 10-hr interruption were acceptable in the area of interest, the commander could ban entry to it for that length of time. Otherwise, he could determine whether to revise the riak factor upward. Knowing that the delay could possibly be only $1 \mathrm{hr}$, he could reasonably sit tight and wait for data that could be used to better establish the actual yield by inductive methods.

To continue the scenario, suppose the data coming in indicate that a 20-kt weapon is producing fallout. To prevent radiation dose level 6 from exceeding $20 \mathrm{rad}$, the area cannot be traversed until after a delay of $6 \mathrm{hr}$ (see Eig. A-7 in Appendix $A, l=10 \mathrm{~m}$ ). However, if the troop units could reach a point $15 \mathrm{mi}$ from ground zero, they would experience a low level of radiation without any further delay in crossing the area.

The ability of the field commander to answer the many "what if?" questions rapidly and comprehensively is a measure of how the modern army can respond to nuclear threats on the tactical battlefield.

\section{Summary}

The transfer of predictive schemes from forecasting radiation fallout patterns under stabilized test conditions in isolated areas to use under battlefield conditions has numerous drabacks. Foremost of the difficulties is the determination of yield from an unknown nuclear weapon. The problem includes measuring the effects as well as using these effects as an accurate gauge of yield. Fur thermore, the radioactive debris is influenced by many factors that have resisted satisfactory modeling (Table 3 ). 
Table 3. Problems that have not been modeled satisfactorily.

\begin{tabular}{|c|c|c|}
\hline Influence & Problem & Solution deterrent \\
\hline \multirow[t]{3}{*}{ Wind field } & $\begin{array}{l}\text { 1. Assumption of uniform } \\
\text { direction in any stratum }\end{array}$ & $\begin{array}{l}\text { 1a. Requires exhaustive data base } \\
\text { 1b. Overly complex computer program } \\
\text { ming }\end{array}$ \\
\hline & 2. Data accuracy & 1a. Human factors \\
\hline & & 2b. Instrumentation \\
\hline \multirow{2}{*}{$\begin{array}{l}\text { Wind } \\
\text { variability }\end{array}$} & 1. Data updating & 1a. Manpower limitations \\
\hline & & 1b. Communications jam \\
\hline \multirow[t]{3}{*}{ Terrain } & 1. Topography description & 1. Cataloging limitations \\
\hline & 2. Shielding factors & 2. Local peculiarities \\
\hline & 3. Microrelief & 3. Resolution of data \\
\hline \multirow[t]{2}{*}{ Dispersion } & 1. Fractionation & 1. Incomplete theory \\
\hline & 2. Fission/yield ratio & 2. Undefined weapons \\
\hline Rainout & 1. Microclimate forecasting & 1. Mother Nature \\
\hline \multirow[t]{3}{*}{ Cloud size } & 1. Measurement & 1a. Instrumentation \\
\hline & & 1b. Short "time-window" for data \\
\hline & 2. Yield calculation & 2. Wide interpretation tol erances \\
\hline
\end{tabular}

There have been attempts to build very detailed computer programs for prediction. These have resulted in inordinately long machine-run times, even on the largest computers available. The trend has since been to simplify prediction programs for the sake of making them more useful.

Many caveats exist in the literature and field manuals for the prediction user not to get too confident about the results he obtains. Official military doctrine cautions commanders not to order maneuvers solely on the basis of prediction results. First-hand observations of aberrant test results may have led these sober warnings.

This review of prediction techniques, together with their complexities and complications, should emphasize the need for a battlefield radiation assessment and simulation system. It should be clear that there can be no substitute for hard facts about the situation in a tactical nuclear conflict. Some radiation assessment methods do exist, but only in elemental form, using manual techniques. An evaluation of how assessment capabilities should be upgraded is the sutject of further study.

The Weapons Effects Display System was a start toward automation of radiationdata processing for field use. It was used for prediction schemes and coupled the results to display hardware. The next step-computerization of radiation-data collection, reduction, and display-remains to be taken. 


\section{References}

1. J. E. Reeves, Operation Teapot-Report of the Test Manager, AOAEC (Dec. 1957) (title U, report SRD).

2. J. F. Reeves, Operation Plumbbob-Report of the Test Manager, AOAEC (Dec. 1957) (title U, report SRD).

3. Capabilities of Nuclear Weapons, Rept. DASA EM-1 (January 1968), p. 4-12 (title $U$, report $\mathrm{C}$ ).

4. R. N. Lessler, Schooner Preshot Analys is, Lawrence Livermore Laboratory, Rept. UCRL-50530 (1968) (title U, report SRD).

5. T. A. Gibson, Schooner Gamma Fallout Field, Lawrence Livermore Laboratory, Rept. UCRL-56958 (1970) (title U, report SRD).

6. S. Glasstone, The Eiffects of Nuclear Weapons, Atomic Energy Commission (April 1962).

7. Capabilities of Nuclear Weapons, Rept. DASA EM-1 (January 1968), p, 4-44 (title $U$, report $C$ ).

8. Fallout Prediction, Department of the Army, TM 3-210 (December 3, 1967).

9. C. J. Scury and M. Polan, An Analysis of Fallout Prediction Models Presented at USNRDL-DASA Fallout Symposium of September 1962, Vol. II, Rept. USNRDL NR DL-TRC-68 -99 (28 August 1968).

10. The Department of Defense Land Fallout Prediction System, Vols. I-VII, Repts. DASA 1800 Series (1966-1968).

11. C. F. Miller, Biological and Radiological Effects of Fallout from Nuclear Explosives, Rept. NRDL URS 702-1, TRC-68-61 (May 1969).

12. D. K. Winegardner, PROFET: A Hapid Method for Generating Fallout Predictions from Field Dates, Edgewood Arsenal, Rept. NDL-TR-124 (May 1969).

13. Winegardner, p. 178.

14. H. Lee, P. W. Wong, and S. L. Brown, SEER II: A New Damage Assessment Fallout Model, Stanford Research Institute, Rept. DNA-300BF (May 1972).

15. Lee et al., p. 52.

16. Lee et al., p. 3 .

17. J. B. Knox, T. A. Gibson, and L. A. Lawson, KDFOC: A Computer Program to Calculate Fallout from Underground and Land Surface Nuclear Explosions, Lawrence Livermore Laboratory, Rept. UCRL-51179 (1972) (title U, report SRD).

18. C. W. Berndt and D. E. Ferguson, Weapons Effects Display System (WEDS MOD II), Lawrence Livermore Laboratory, Rept. UCRL-50892 (1971).

19. C. W. Berndt, A General Description of the Weapons Effects Display System (WEDS MOD II), Lawrence Livermore Laboratory, Rept. UCRL-50922 (1970).

20. A. D. Anderson, The NRDL Dynamic Model For Fallout From Land-Surface Nuclear Bursts, Rept. NRDL-TR-410 (April 5, 1960 ).

21. Fallout Prediction, op. cit., p. 43 . 
22. Operational Aspects of Radiologicill Defense, Department of the Army, FM3-12 (August 1970), Change 1.

23. H, R. Rinnert, Intercomparison of Operational and Computer Fallout-Prediction Systems, Rept. NRDL-TR-69-49 (July 1, 1969).

24. S. H. Cassidy, The FORTRAN Statement of the Transport Module for a Generalized Land Fallout Model Computer Program, Rept. NRDL-TR-68-67 (June 6, 1968).

25. R. Goldstein, The TERF Program and Its Application to the Calculation of Fallout Radiation Dose, Rept. NRDL-TFC-63-56 (January 1969).

26. J. M. Ferguson, Ground Roughness Eiffects for Fallout-Contaminated Terrain: Comparison of Measurements and Csilculations, Rept. NRDL-TR-645 (May 7, 1963 ).

27. R. L. Mather, Ground Roughness Effects in Fallout Radiation Fields-Problems of Analysis of Measurements, Rept. NRDL-TR-68-62 (March 29, 1968).

28. R. L. French, "On The Buried-Source Model for Computing Fallout Ground Roughness Effects," Healti: Phys. 14. 331 (1968).

29. E. M. Artemor et al., "Surface $\gamma-S$ fectrometry of Local Radioactive Contamination," Soviet Atomic Energy 31 (I), 725 (July 1971).

30. Y. A. Izrael, "Effect of Ground Roughness on the $\gamma$ Field Above a Region Contaminated by Radioactive Fallout," Soviet Atomic Energy 17 (2), 845 (August 1964).

31. K. Koroler, Learning to Use Terrain Skillfully, USSR Ministry of Defense, translation FSTC-HT-23-1096-68 (1955).

32. R. R. Rapp, An Error in the Prediction of Fallout Radiation, RAND Corp., Rept. RM-5164-PR, (December 1966).

33. J. B. Knox, T. V. Crawford, and W. K. Crandall, Potential Exposures From Low-Yield Free-Air Bursts, Lawrence Livermore Laboratory, Rept. UCRL-51164 (1971).

34. W. K. Crandall, C. R. Molenkamp, A. L. Williams, M. M. Fulk, R. Lange, and J. B. Knox, An Investigation of Scavenging of Radioactivity from Nuclear Debris Clouds: Research in Progress, Lawrence Livermore Labcratory, Rept. UCRL-51328 (1973).

35. W. W. Kellogg, The Height and Size of Atomic Clouds, RAND Corp. Rept. RM-1378-AEC, (November 1954), (title U, report SRD).

36. M. J. Landry and J. R. Lochner, Laser Light Detecting and Ranging (LIDAR) Systems, Sandia Laboratories, Albuquerque, N. Mex., Rept. SC-DR-67-850 (1968).

37. J. W. Oblanas and R. T. H. Collis, Lidar Observations of the Pre-Gondola Clouds, Stanford Research Institute, Rept. PNE-1110 (July 1967).

38. J. W. Oblanas and R. T. H. Collis, Lidar Observations of Debris Clouds from Nuclear Cratering Detonations, Lawrence Livermore Laboratory, Rept. UCRL13451 (1968).

39. W. E. Evans, E. J. Wiegman, W. Viezee, and M. G. H. Ligda, Performance Specifications for a Meteorological Satellite Lidar, Stanford Research Institute, Rept. NASA-CR-76087 (June 1966). 
40. P. V. Colmar and R. T. Williams, Development of An Airborne EHF Radar System for Cloud Detection, Lawrence Livermore Laboratory, Rept. UCRL50195 (1967).

41. Guide to Meteorological Instrument and Observing Practices, World Meteorological Organization, No. 8. TP3 (1971) 4th ed., p. XVI.9.

42. Employment of Radioactive Fallout as a Weapon, U.S. Army CDC (August 1964) (title U, report SRD).

43. M. R. Gustayson, R. K. Squire, R.C. Orphan, and R. P. Gard, Au Examination of Tactical Nuclear Weapons, Lawrence Livermore Laboratory, Rept. UCRL51294 (1972) (title U, report SRD).

44. Organizational, Technical and Logistical Data, Department of Army, Staff Officers' Field Manual, FM101-10-1, September 1969.

45. Operational Aspects of Radiological Defense, Department of Army, FM3-12 (August 1970). 


\section{Appendix}

For this study, the range of nuclear-weapon yields considered probable to be encountered in a tact: al nuclear battle was 10 to $100 \mathrm{kt}$. Within this range, a set of equations relating doise rates to distance can be derived from the idealized fallout models given by DNA. ${ }^{7}$ These are shown graphically in Figs. A-1 anc A-2 and are of the form

$$
\text { Dose rate }=\mathrm{Ke}^{-\mathrm{cW}}=\mathrm{Ke}^{-\mathrm{d} \ell} \text {, }
$$

where:

$$
\text { K, c, and } \begin{aligned}
d & =\text { constants dependent on weapon yield, } \\
w & =\text { maximum width of isodose line, } \\
f & =\text { maximum length of isodose line. }
\end{aligned}
$$

The dose rate decays at a fairly consistent rate, as indicated in Fig. A-3. The $t^{-1.2}$ decay curve fits experimental data very well. Since the $\mathrm{H}+1-\mathrm{hr}$ characteristic radiation pattern is decaying, a person walking through such an area would experience unsymmetrical dose levels, as indicated by Fig. A-4. The 10-R/hr isodose line serves to mark the entry and exit from an intense radiation area. Total-dose calculations are of the form

$$
\text { Total dose }=\int_{t_{1}}^{t_{2}} D R=\int_{t_{1}}^{t_{2}} \frac{K}{t^{1.2}} e^{-c w(t)} d t
$$

where:

$$
\begin{aligned}
\mathrm{DR} & =\text { dose rate } \\
t & =\text { time. }
\end{aligned}
$$

This may be solved by integration by parts:

$$
\int_{t_{1}}^{t_{2}} \frac{\mathrm{K}}{\mathrm{t}^{1.2}} \mathrm{e}^{-\beta \mathrm{t}} \mathrm{dt}=-\frac{\mathrm{Ke}}{\gamma \mathrm{t}^{-\beta \mathrm{t}}}+\frac{1.2}{\gamma \mathrm{t}} \frac{\mathrm{Ke}}{\gamma \mathrm{t}^{-\beta \mathrm{t}}}-\frac{2.2}{\gamma \mathrm{t}} \frac{1.2}{\gamma \mathrm{t}} \frac{\mathrm{Ke}}{\gamma \mathrm{t}^{-\beta \mathrm{t}}}+\ldots
$$

where:

$$
\begin{aligned}
\beta \mathrm{t} & =\mathrm{c}\left|\mathrm{x}_{0}+\mathrm{m}\left(\mathrm{t}-\mathrm{t}_{1}\right)\right|, \\
\gamma & =\mathrm{cm}, \\
\mathrm{m} & =\text { rate of march. }
\end{aligned}
$$

However, this is a cumbersome calculation to make and can be done easier by summation of small increments that can be performed on digital processors more readily. The above then becomes

$$
\text { Total dose }=\sum_{t_{1}}^{t_{2}} \frac{K}{t^{1.2}} e^{-2 c|x(t)|} \Delta t
$$




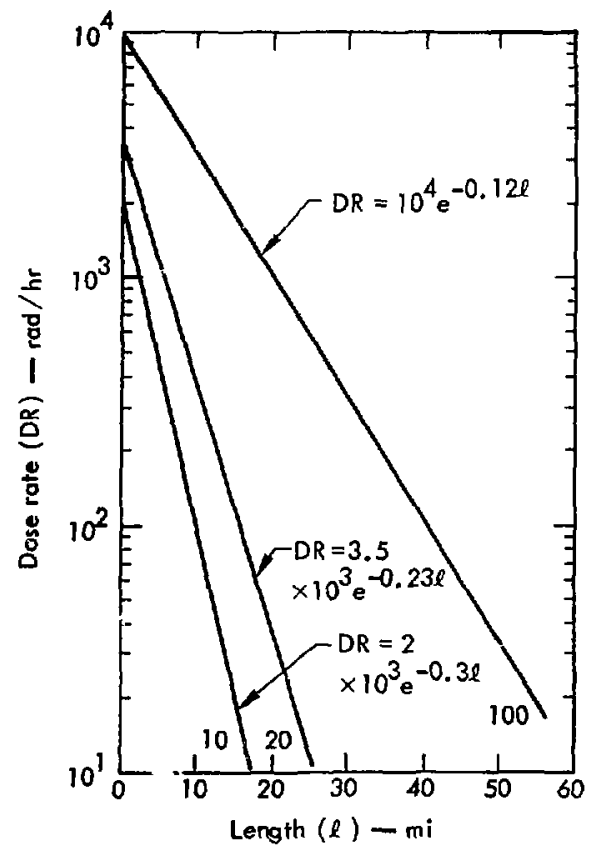

Fig. A-1. Dose rate versus distance from ground zero at $\mathrm{H}+1 \mathrm{hr}$ for 10,20 , and $100 \mathrm{R} / \mathrm{hr}$ Isodose lines; the wind is 10 knots.

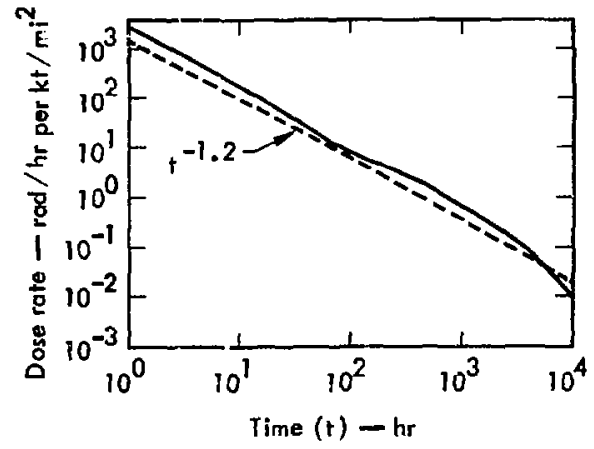

Fig. A-3. Fission-product delay.

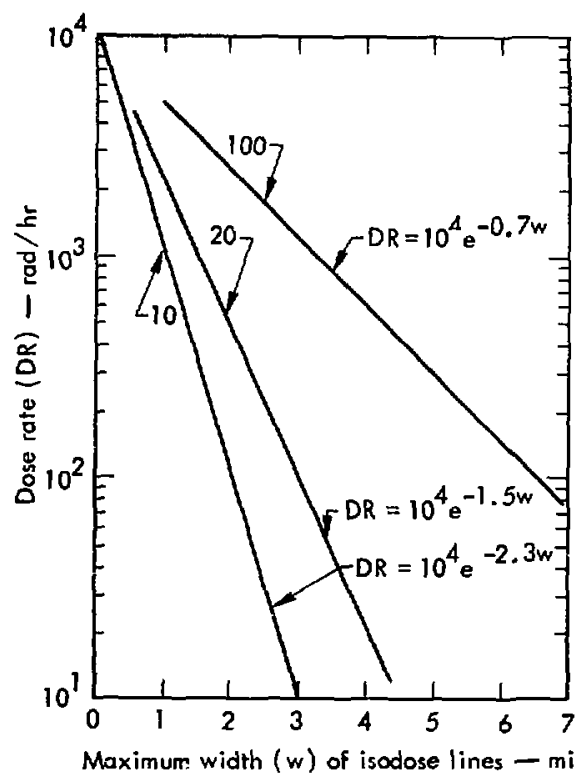

Fig. A-2, Dose rate versus maximum width of $10-, 20-$, and 100-R/hr isodose lines; the wind is 10 knots.

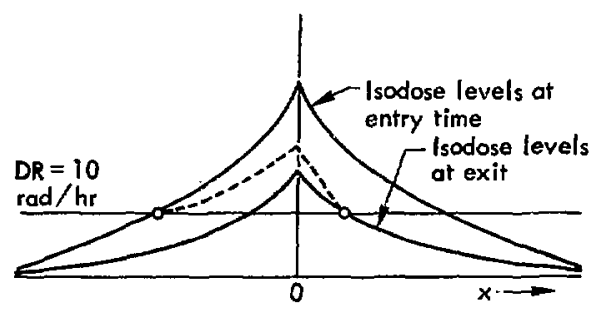

Fig. A-4. Dose-rate levels experienced because of time decay (dashed line). 
The form factor of the pattern must also be taken into account. For convenience, the idealized patterns are assumed to be ellipses, as depicted in Fig. A-5. The equation describing an ellipse at the origin is

$$
\frac{(y-a)^{2}}{a^{2}}+\frac{x^{2}}{b^{2}}=1 \text {. }
$$

Since, from Fig. A-1 and the decay curve,

$$
\mathrm{DR}=\frac{\mathrm{K}}{\mathrm{t}^{1.2}} \mathrm{e}^{-\mathrm{d} \ell}
$$

where $d$ is a constant dependent on yield, and substituting

$$
\begin{aligned}
2 a_{0} & =l \\
x_{0} & =b
\end{aligned}
$$

then

$$
\mathrm{a}_{\mathrm{o}}=\left.\frac{-1}{2 \mathrm{~d}} \ln \frac{\mathrm{DR}}{\mathrm{K}} \mathrm{t}^{1.2}\right|_{\mathrm{DR}=10 \mathrm{rad}}
$$

and

$$
x_{0}=-\left.\frac{1}{2 c} \ln \frac{D R}{K} t^{1.2}\right|_{D R=10 \mathrm{rad}}
$$

Solving for $\mathrm{x}$ :

$$
x^{2}=x_{0}^{2}-\frac{\left(y-a_{0}\right)^{2} x_{0}^{2}}{a_{0}^{2}} .
$$

A few of the typical results from calculations and plots run on an office calculator-plotter are shown in Figs. A-6 through A-8. 


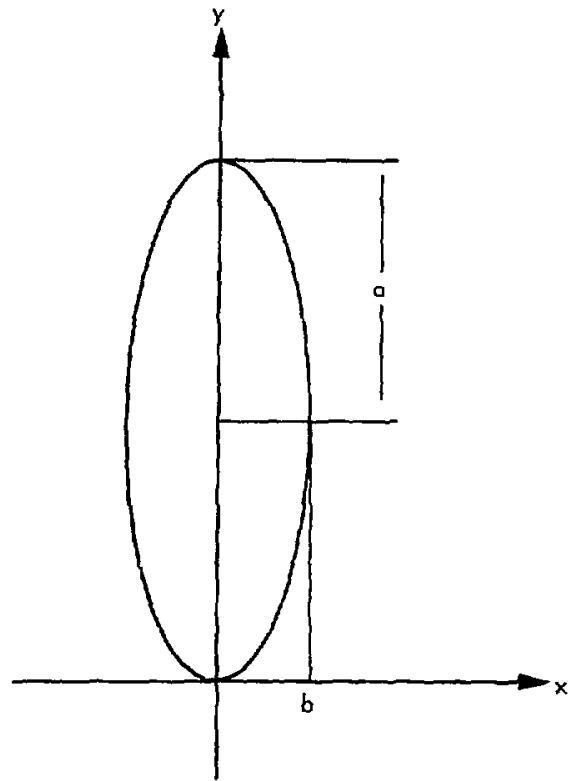

Fig. A-5. Isodose ellipse with focus at origin (ground zero).

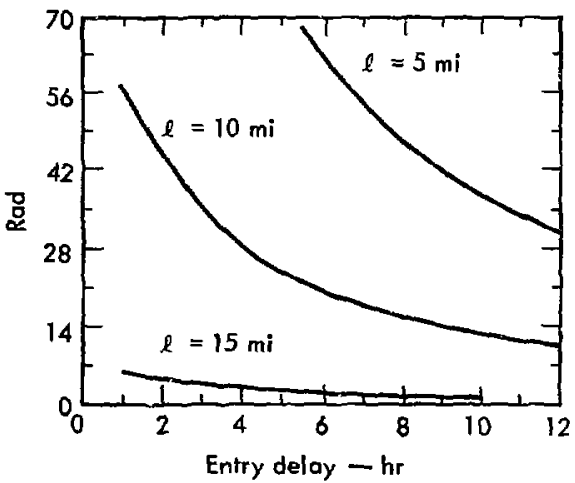

Fig. A-7. Total radiation exposure after area-entry delay, for various distances from ground $z$ ero of a 20-kt detonation. The expected march rate is $1 \mathrm{mph}$.

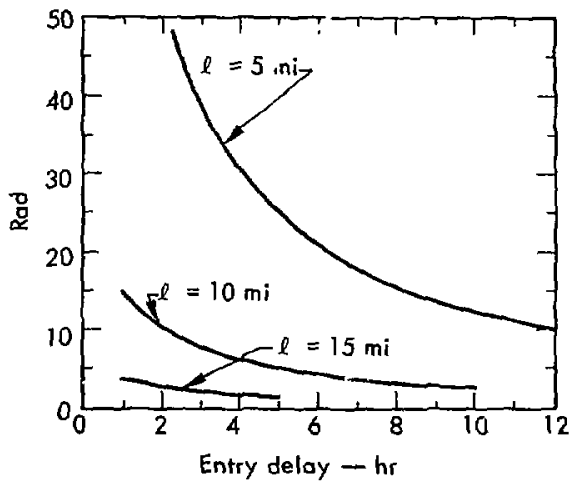

Fig. A-6. Total radiation exposure after area-entry delay, for various distances from ground zero of a 10-kt detonation. The expected march rate is $1 \mathrm{mph}$.

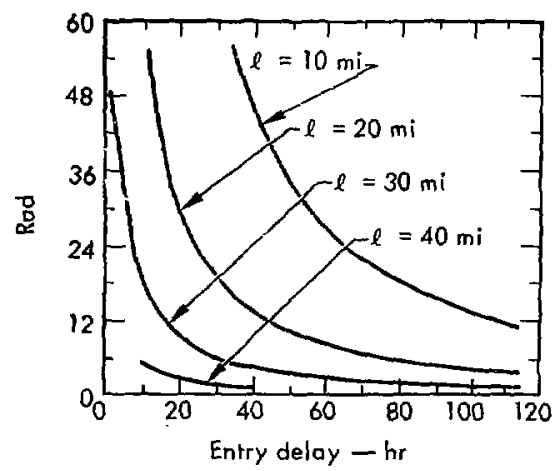

Fig. A-8. Total radiation exposure after area-entry delay, for various distances from ground zero of a 100-kt detonation. The expected march rate is $1 \mathrm{mph}$. 